\title{
Bronze Age Globalisation and Eurasian Impacts on Later Jōmon Social Change
}

\author{
Mark J. Hudson ${ }^{1,2} \cdot$ Ilona R. Bausch ${ }^{3,4,5} \cdot$ Martine Robbeets $^{1} \cdot$ Tao $\mathrm{Li}^{6}$. \\ J. Alyssa White ${ }^{7} \cdot$ Linda Gilaizeau $^{1}$
}

Accepted: 25 May 2021 / Published online: 7 July 2021

(c) The Author(s) 2021

\begin{abstract}
From northern China, millet agriculture spread to Korea and the Maritime Russian Far East by 3500-2700 BC. While the expansion of agricultural societies across the Sea of Japan did not occur until around $900 \mathrm{BC}$, the intervening period saw major transformations in the Japanese archipelago. The cultural florescence of Middle Jōmon central Honshu underwent a collapse and reorganisation into more decentralised settlements. Mobility increased as Late Jōmon influences spread from eastern into western Japan, and populations expanded to offshore islands such as Okinawa and the Kurils. In Kyushu and other parts of western Japan, the eastern Jommon expansion was associated with the cultivation of adzuki and soybeans but, contrary to earlier assessments, there is no evidence for the introduction of cereal crops at this time. Here, we analyse archaeological and historical linguistic evidence of connections between the Eurasian mainland and the Japanese Islands c. 3500 to 900 BC. A re-evaluation of archaeological material discussed since the 1920 s concludes that the transformations in Jōmon society during this period were at least in part a response to contacts with Eurasian Bronze Age cultures. Evidence for linguistic contact between Koreanic and the Ainuic languages which are presumed to have been spoken by Jōmon populations is also consistent with new Bronze Age mobilities. Although prehistoric Japan was one of the most isolated regions of Eurasia, we conclude that the historical evolution of societies in the Japanese archipelago after the third millennium BC was linked with processes of Bronze Age globalisation.
\end{abstract}

Keywords Farming dispersals · Globalisation · World system · Language contact · Bronze age $\cdot$ Eurasia $\cdot$ Korean peninsula $\cdot$ Japanese archipelago $\cdot$ Jōmon

\section{Abstract}

紀元前 3500-2700 年頃、アワ・キビ農耕が中国東北部から朝鮮半島と極東口 シアに広がった。農耕社会が実際に日本海を渡るのは、時代をはるかに下る

Mark J. Hudson

hudson@shh.mpg.de

Extended author information available on the last page of the article 
紀元前900年頃まで待たねばならない。しかし、この時期、日本列島の縄文 社会にも大きな变化がみられる.中部地方の縄文中期文化の輝きは失われ、 大型集落は放棄され、分散型居住パターンへと社会の再編成が行われた. 縄 文後期の文化要素が東から西日本へ広がり、琉球列島や千島列島等の離島 への移動が多くなり、社会の流動性が増した。九州等、列島西部では、東方 からの縄文文化がダイズ・アズキ栽培と共に広がった。一方、この時期には 穀物栽培の証拠は認められていない. 本論では、考古学と言語学の分析によ り起源前 3500 900 年頃の間のューラシア大陸と日本列島の交流について検 討する.そのうえで、1920 年代以来議論された考古資料の再評価の結果、 縄文後晚期の社会变化は少なくても部分的には大陸の青銅器時代文化との 接触に起因すると論じる。縄文人が話したと推定されるアイヌ語族(Ainuic) と朝鮮語族 (Koreanic) との言語的交流も青銅器時代の新しい流動性と一致 する. 先史時代の日本列島はューラシアで最も孤立した地域の一つだったに も関わらず、紀元前3千年紀後の列島の歴史的展開は青銅器時代のグローバ リゼーションのプロセスと関連していたと結論する.

\section{Introduction}

From northern China, millet farming spread to the easternmost parts of continental East Asia-Korea and the Maritime Russian Far East-from around 3500 BC (Ahn, 2010; Crawford \& Lee, 2003; Kuzmin, 2013a; Lee, 2011, 2016; Miyamoto, 2014; $\mathrm{Li}$ et al., 2020). However, the expansion of continental agricultural societies across the Sea of Japan did not occur until some 2500 years later at around 900 BC (Miyamoto, 2018; Shoda, 2010). Here, we investigate major transformations in Jōmon societies of the Japanese Islands ca. 3500 to 900 BC. During this time, the cultural florescence of Middle Jōmon central Honshu underwent a collapse and reorganisation into more decentralised settlements. The Late Jōmon cultures of eastern Japan influenced those of the western archipelago, and populations expanded to offshore islands such as Okinawa and the Kurils. In the main islands of western Japan, this expansion was associated with the cultivation of plants such as adzuki and soybeans, and with eastern Jōmon ritual practices (Kobayashi, 2001; Matsumoto, 2005; Obata, 2016; Teramae, 2017).

Previous research has usually regarded Jōmon Japan as a self-contained system more or less isolated from the continent until the sudden arrival of migrants from Bronze Age Korea at the beginning of the Yayoi period (e.g., Imamura, 1996). Yamanouchi (1932) defined the Jōmon as a culture which-in contrast to the following Yayoi-lacked significant contacts with the Eurasian continent. Takahashi et al. (1998, p. 69) note that the Jōmon has been conceived 'as an autonomous entity insulated from the mainland Asia.' The presence of some continental artefacts in Jōmon Japan and Jōmon artefacts at a few sites in southern Korea has been known for some time (Bausch, 2016). Kikuchi (1986) has also discussed prehistoric exchange between Hokkaido and the continent. However, it is usually assumed that the long-term impacts of such interaction were limited. Here, however, we argue that the dynamic changes experienced in later Jomon society are best explained by 
Table 1 Chronology for southern Korea and the Japanese Islands. Based on Barnes (2015) and Kawashima (2008)

\begin{tabular}{ll}
\hline Southern Korea & Japanese Islands \\
\hline Middle Neolithic (Chulmun) 3500-2000 BC & Middle Jōmon: 3630/3550-2580/2510 BC \\
Late Neolithic (Chulmun) 2000-1500/1000 BC & Late Jōmon: 2580/2510-1260/1230/1220 BC \\
Early Bronze Age (Mumun) 1450-850 BC & Final Jōmon: 1260/1230/1220-900 (north \\
& Kyushu)/200 BC (east Honshu) \\
Middle Bronze Age (Mumun) 850-500 BC & Yayoi: 900 (north Kyushu)/200 (east Honshu) \\
& BC-AD 250/300 \\
Late Bronze Age (Mumun)/Early Iron Age 500-200 & Epi-Jōmon: 300 BC-AD 700 (Hokkaido and \\
BC & northern Honshu) \\
\hline
\end{tabular}

assuming that the local and the global are mutually constitutive and by consequently analysing Japan and continental East Asia as part of the same Eurasian system.

Table 1 shows the chronology of the main periods considered for the Korean peninsula and the Japanese islands. The terms Neolithic and Bronze Age are used as 'world historical epochs' wherein 'communities, even when not directly connected to each other, shared basic conditions that enabled and constrained their evolutionary potential' (Kristiansen, 2015, p. 1093). The Eurasian Neolithic was characterised by pottery, sedentism and agriculture, but because local expressions of the Neolithic employed those attributes at varying levels of intensity, there has been a longstanding debate over whether particular cultures were or were not 'Neolithic' (Gibbs \& Jordan, 2016; Kuzmin, 2013b) or whether they were or were not 'farmers' (Crawford, 2008). If we assume that these local expressions were part of a broader Neolithic epoch (sensu Kristiansen), then the problem shifts from a typological exercise in trait listing to the more interesting issue of how the various Neolithic cultures across Eurasia reacted to shared social and economic conditions. While classifying the Bronze Age might at first seem to be a simpler task, in East Asian archaeology there has been controversy over whether the actual presence of bronze is required to define that period (Shoda, 2010). In Korea, for example, the Bronze Age is often defined by Mumun ('Plain Pottery') which was used several hundred years before the appearance of bronze (Norton, 2007, p. 137; Bae \& Kim, 2015). The term 'megalithic period' is also sometimes used for this stage (see Nelson, 1993; Bale, 2001). Such definitional problems confuse inter-regional comparisons. The peninsula populations who moved to Kyushu in the tenth century BC would normally be termed 'Bronze Age' in Korea, but because bronze is only commonly found in Japan from the fourth century BC, the first half of the Yayoi is termed 'Neolithic' by Teramae (2017, p. 2). In the Russian Far East, where bronze is also rare until quite late, the term 'Bronze Age without Bronze' has been used (Tabarev, 2014, p. 864).

On a Eurasian scale, the Bronze Age was an epoch characterised by decentralised political economies in which long-distance trade in metals and other goods played a central role (Childe, 1950; Kristiansen, 2015; Kristiansen \& Larsson, 2005; Scott, 2017). High mobility was associated with Bronze Age warrior elites as well as with trade (Kristiansen, 2006). The Bronze Age also saw large-scale movements 
of languages and populations (Allentoft, 2015). In the context of Jōmon Japan, the concept of world historical epochs can be regarded as a hypothesis requiring further evaluation. If, for example, the Bronze Age in East Asia began in the third millennium BC, does that mean that the contemporary Late and Final Jōmon cultures of Japan should also be classified as Bronze Age? This is not a question that can be simply answered 'yes' or 'no'; rather, the issue is to examine in what ways the Late and Final Jōmon may have been influenced by Bronze Age societies on the Eurasian mainland. Did, for example, the Bronze Age constitute a 'world system' (Frank, 1993; Ratnagar, 2001)? Or are theories of ancient globalisation and 'bronzisation' (Vandkilde, 2016) more suited to understanding the historical trends of the time? We shall return to these questions below.

\section{Social Change in the Middle to Final Jōmon: Overview}

The end of the Middle Jōmon saw major changes across Japan. Cultivation of adzuki (Vigna angularis var. angularis) and soybeans (Glycine max) had, at least in part, supported the population increase and cultural florescence of the Middle Jomon cultures of central Honshu (Nakayama, 2010; Obata, 2016). At the end of the Middle phase, however, these cultures underwent reorganisation into more decentralised settlement strategies (Imamura, 1996; Twiss, 2001; Kawashima, 2013). A precipitous drop in the number of pit houses is thought to represent a major population decline (Imamura, 1996). By the latter half of the Final phase, it is hard to find any examples of pit houses in the Kanto and Chubu regions (Hudson, 1999, p. 140; Ishikawa, 2010 , p. 43). In eastern Japan, settlement patterns underwent a shift from 'clumped' to 'dispersed' patterns (Uchiyama, 2006, 2008). While the 'clumped' pattern was marked by concentration at a few central places with much smaller peripheral sites, in the 'dispersed' pattern, site size difference is almost non-existent. However, regional and chronological variation exists and many parts of western Japan saw an increase in both site numbers and size in the Late Jōmon (Bausch, 2016; Koyama, 1978).

Stone circles had been known since the Incipient Jōmon (Uchiyama, 2017), but these monuments became much more common in the Late and Final phases in the Tohoku and Hokkaido (Habu, 2004, pp. 182-187; Naumann, 2000, pp. 33-40; Kodama, 2003). Other distinctive monuments of the Late Jōmon in southwest Hokkaido are large circular embanked burials, which often have rich grave goods (Ikawa-Smith, 1992; Sakaguchi, 2011). The largest of these embanked burials, tomb 2 at the Kiusu site, has a diameter of $75 \mathrm{~m}$ and a height of $5 \mathrm{~m}$ (see Fig. 1 for site locations). This is not only the largest Jōmon burial but also the largest tomb found in Japan prior to the end of the Middle Yayoi (Teramae, 2017, p. 50). Several archaeologists have seen these monuments and their presumed associated rituals as a means by which normally dispersed groups reproduced their internal social cohesion (Ikawa-Smith, 1992; Ishikawa, 2010, pp. 46-47). Others have proposed that the monuments were a means of dealing with the contradictions of growing social inequality (Takahashi, 2004; cf. Takase, 2020). There had been an increase in the diversity and complexity of burials from the Middle Jōmon. Secondary burials in large 


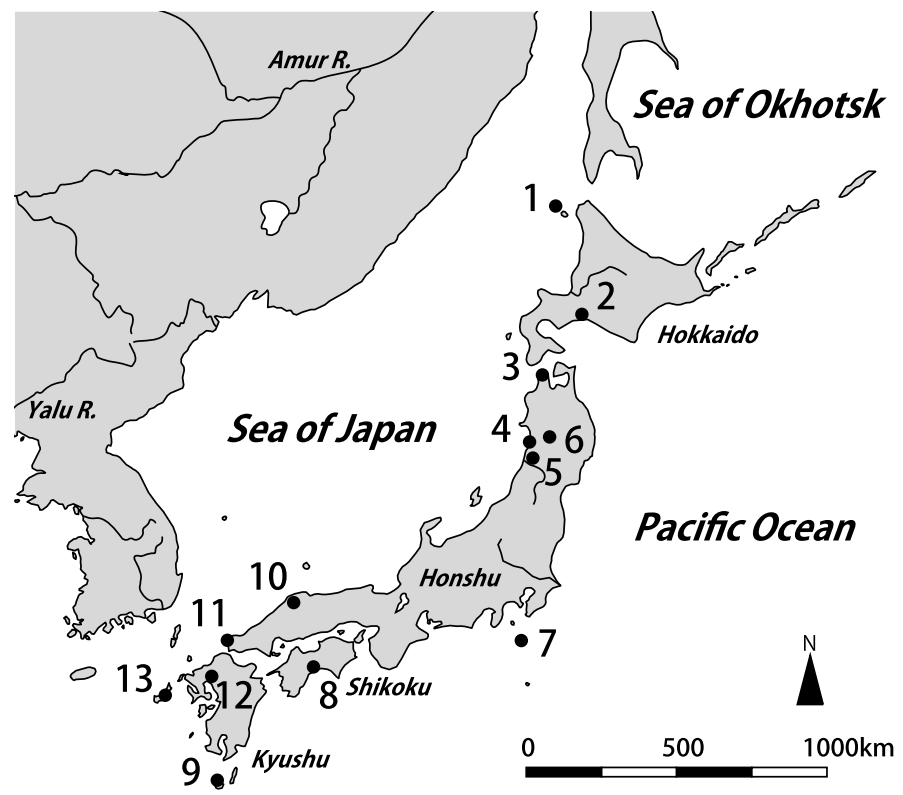

Fig. 1 Map of the Japanese Islands showing main sites mentioned in the text. 1: Funadomari; 2: Kiusu; 3: Imazu; 4: Misakiyama; 5: Nakagawadai; 6: Uwahaba; 7: Tabara; 8: Itoku; 9: Yokomine; 10: Itaya III; 11: Doigahama; 12: Etsuji; 13: Miyashita. Map by J. Uchiyama

pits or jars are known from the Late and Final phases (Habu, 2004, pp. 169-174; Ishikawa 2014). Based on analyses of burials in eastern Japan, Nakamura (1999) argued that hereditary social inequality increased at this time. From the Late phase, the use of curved magatama beads as grave goods suggests individual ownership (Nishimura, 2018). After the early phase of the Late Jomon there is a clear shift in the form, usage and social value of jadeite ornaments, which might be related to increasing social complexity and overall greater variety of prestige and symbolic material culture (Bausch, 2010a). In the Late and particularly the Final Jōmon, there is evidence for feasting and for the craft production of fine pottery and lacquerware (Kawashima, 2008, 2010, 2015a; Matsumoto, 2018a).

Late and Final sites in western Japan were subject to numerous influences from the eastern Jōmon, including styles of pottery decoration, pit-house hearths lined with stones, chipped stone axes, polished stone swords and daggers, clay figurines, and tooth ablation (Kaner \& Ishikawa, 2007; Kobayashi, 2001; Matsumoto, 2005, 2011; Nishimura, 2018). As well as new social networks, it has been argued that these influences may have been due to population migrations from eastern to western Japan (Matsumoto, 2011; Matsumoto et al., 2017). Adzuki and soybean cultivation expanded into western Japan (Obata, 2016), but in the eastern archipelago the intensification of legume farming was apparently reduced in favour of a broader spectrum of food resources (Sasaki \& Noshiro, 2018). Increased consumption of horse chestnuts (Aesculus turbinata) was associated with a new type of processing facility termed 'water reservoirs', which are assumed to have been used to leach toxic aloin 
and saponin from these nuts (Kawashima, 2016). In western Japan, the Late-Final phases were associated with wet storage pits for deciduous acorns, which require less leaching (Kawashima, 2016; Hosoya, 2011). In Hokkaido, sea-mammal hunting became more important from the second half of the Middle Jōmon; while this has been linked with climatic cooling (Yamaura, 1998), there was also an increase in specialised fishing of large prey such as swordfish and olive flounder (Paralichthys olivaceus, also known as 'bastard halibut') in the Final Jōmon and early Epi-Jōmon phases (Takase, 2020). Hudson (2020a) has argued that these changes in Late-Final Jōmon subsistence must also be seen against the background of a reluctance to follow the Neolithic pattern of complexity into full-scale agriculture.

Many offshore islands in the Japanese archipelago had been visited since the Palaeolithic (Bae, 2017; Hashiguchi, 1994; Ikeya, 2015; Nakazawa \& Bae, 2018; Takamiya et al., 2016), and obsidian had been exchanged between Kyushu and the Korean peninsula as early as 20,000 years ago (Kim et al., 2007), but in the Late Jōmon there was a significant increase in the exploitation of offshore islands. The Okinawa archipelago saw a noticeable growth in site numbers in the Late and Final Jōmon (Takamiya et al., 2016, p. 415). In Hokkaido, despite an overall decline in site numbers (Abe et al., 2016), offshore islands were exploited more intensively from the Late phase. On Rebun Island, $60 \mathrm{~km}$ northwest of Hokkaido, the first clearly residential site dates to the late Middle phase, and there was an increase in site numbers from the Late Jōmon (Sakaguchi, 2007, p. 29). Radiocarbon proxy data from the Kurils suggest increased exploitation of these islands in the Late and Final Jomon (Fitzhugh et al., 2016). The far-from-ephemeral nature of many of these island occupations is clear from the stone pavement at the Tabara site on Niijima Island (Tokyo) (Hashiguchi, 1994); the pinniped-hunting and bead-making Funadomari site on Rebun Island (Fujisawa, 2013; Sakaguchi, 2007); and the Yokomine site on Yakushima Island (Kagoshima), where the settlement area seems to have been levelled through large-scale earthworks prior to the construction of several dozen Late Jōmon pit houses (Matsumoto, 2005, pp. 156-157). The Late to Final Jōmon saw an increase in the number of excavated dugout canoes, with almost $80 \%$ of Jōmon canoes dating to those phases, although there is no evidence for changes in seafaring technology at that time (Habu, 2010).

Climatic cooling has been posited as a major factor in the changes in Jōmon society described above. The transition between the Middle and Late Jōmon phases is associated with the period of cooling across the Old World in the third millennium BC (cf. Dalfes et al., 1997). It is thus commonly argued that the socio-ecological framework achieved in the Middle Jōmon became difficult to maintain in the face of such cooling (e.g., Ishikawa, 2010, p. 46). However, a recent study by Sasaki and Noshiro (2018) found no evidence for deterministic models linking cooling with the Late Jōmon 'collapse'; instead, these authors argue that Late Jōmon groups showed a high degree of resilience in managing plant resources in a changing environment. The role of ecological overshoot or environmental degradation around Middle Jōmon sites has also been suggested as a factor in the Late-Final phase transformations (Uchiyama, 2006, 2008). At present there is little empirical evidence supporting this theory, although Koike and Ohtaishi (1985) proposed that hunting pressure on sika deer (Cervus nippon) increased in the Kanto region in the Late and Final 
phases, and an increase in dog burials from the Middle Jōmon has been linked with resource depression as hunting dogs became valued as a specialized technology in eastern Honshu (Perri, 2016). A third hypothesis explaining the Middle-Late Jōmon population decline is epidemic disease (Oikawa \& Koyama, 1981; Kidder, 1995, 2007, p. 309). There is currently no direct evidence for such an epidemic reaching Japan at this time but in light of recent research arguing that Yersinia pestis (the aetiological agent of plague) spread widely across Eurasia, most likely though trade networks, during the 'Neolithic decline' (Rascovan et al., 2019), this possibility cannot be rejected and warrants further analysis.

\section{Middle-Final Jōmon Interactions Between Continental East Asia and Japan}

Despite widespread assumptions that the Jōmon was isolated from the continent, material culture links with the Asian mainland have been noted from at least the 1920s (Kita, 1926, 1927) and were discussed in several early works in English and other European languages (e.g., Groot, 1951; Kagawa, 1968; Kidder, 1957, 1968). Examples of interaction with the mainland exist from the early half of the Jomon period. However, such evidence becomes more common and diverse from the Late Jōmon onwards. Building on our earlier work (Bausch, 2016; Gilaizeau, 2010; Hudson, 1999; Robbeets, 2005, 2017), we conducted a re-evaluation of archaeological and historical linguistic evidence for contact between the Japanese archipelago and continental East Asia during the period from the Middle to the Final Jomonroughly 3500 to $900 \mathrm{BC}$ in Kyushu, though it is important to remember that Final Jōmon culture continued for some 700 years longer in parts of eastern Honshu. From this analysis we concluded that there is no evidence for the spread of Eurasian farmers into Japan at this time. The linguistic contacts discussed below do not seem to reflect a farming/language dispersal of the type proposed by Bellwood (2005). The archaeological evidence also suggests relationships rather different to the forager/farmer frontier model of Zvelebil and Rowley-Conwy (1984; cf. Crawford \& Takamiya, 1990; Barnes, 1993; Zvelebil, 1998; Janik, 1998). Our analysis did, however, find that Jōmon society experienced significant interaction with Bronze Age cultural developments on the mainland. The earliest bronze object in East Asia is a tin-bronze knife from Gansu province, northwest China, dated to c. 2800 BC (Gansu et al., 1984). By the middle of the second millennium BC, the Shang dynasty of the Yellow River basin possessed a fully-fledged bronze culture. On the Korean peninsula, Barnes (2014) dates the first bronze to after $700 \mathrm{BC}$ and the first iron to c. $400 \mathrm{BC}$. In Japan, the first bronze and iron artefacts are thought to date from the fourth-third centuries BC (Teramae, 2017, pp. 189-190). Although only one bronze knife has been discovered from a Jōmon site, the Late and Final phases saw widespread craft production involving skeuomorphism, that is, "the sharing of the formal qualities of objects in order to deliberately evoke an object made in one material in another' (Sofaer et al., 2013, p. 476). The imitation of bronze knives in polished stone appears to be the clearest instance of this phenomenon, but other examples are 
provided by ceramics. The possibility of Jōmon imitations of bronze artefacts was raised by Kita (1926), Yamanouchi (1972) and others, but has received little attention in recent years. Here, we suggest that the time is ripe for a re-evaluation of this material and conclude that the historical evolution of Late-Final Jōmon Japan was significantly affected by Eurasian processes of Bronze Age globalisation.

\section{Cultivated Plants and Domesticated Animals}

Both broomcorn (Panicum miliaceum) and foxtail (Setaria italica) millet had spread from northeast China to Korea by the Middle Neolithic (3500-2000 BC) (Lee, 2016, 2017). The expansion of millet farmers into Korea may have been associated with the linguistic expansion of proto-Koreanic (Robbeets, 2017; Hudson \& Robbeets, 2020) (Fig. 2). Millet cultivation also spread to the Primorye (Maritime) province of the Russian Far East at around the same time (Kuzmin, 2013a; Li et al., 2020; Miyamoto, 2014). Rice farming then reached Korea from the Shandong and Liaodong peninsulas by $1500 \mathrm{BC}$ during the transition to the Bronze Age (Ahn, 2010; Bale, 2001; Lee, 2016; Stevens and Fuller, 2017). Linguistically, this transition may have been associated with proto-Japonic (Robbeets, 2017). Wheat and barley were also found in Korea by the Early Bronze Age (1450-850 BC), although there are reports of these crops from the Middle Neolithic Daech'ŏnri site with direct AMS dates on charred grains of 5430-5110 cal BP (SNU06522 on wheat) and 5110-4890 cal BP (SNU06521 on barley) (1 $\sigma$ calibrated with CalPal 2007_HULU) (Lee, 2016, p.

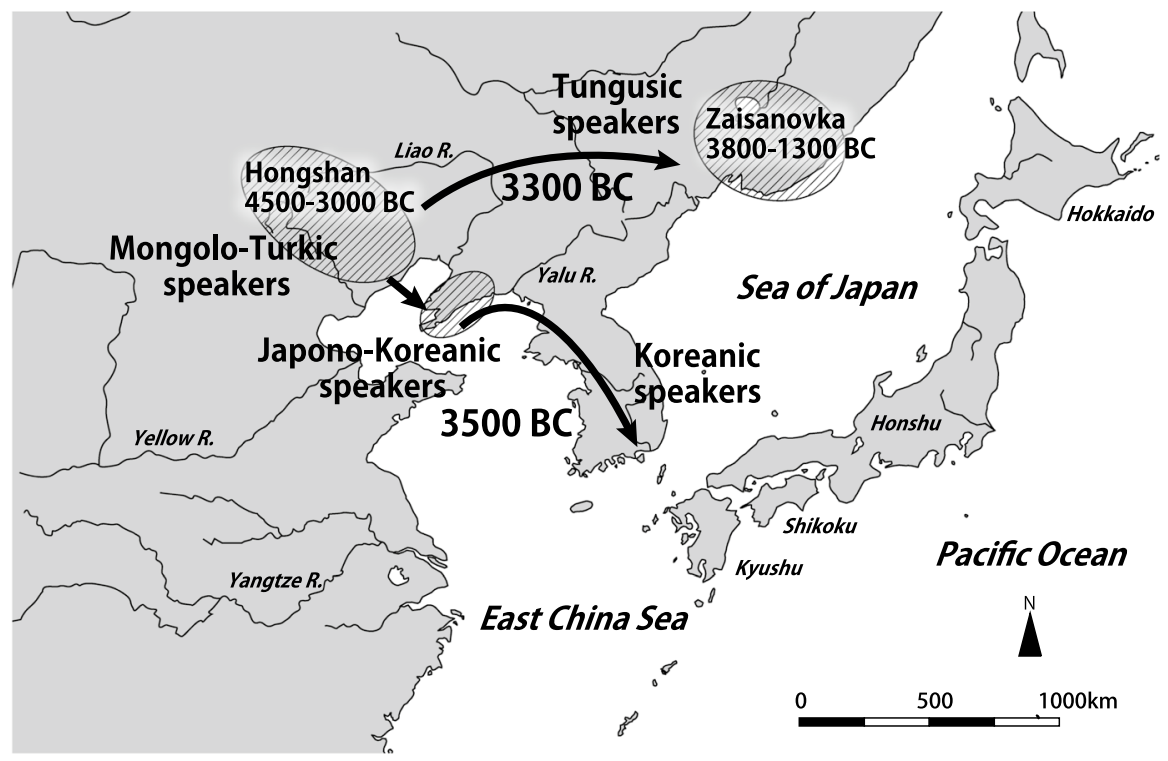

Fig. 2 Expansion of millet farming in northeast Asia in the fourth millennium BC with possible linguistic correlates. Arrows show reconstructed linguistic branching with dates corresponding to the spread of millet. Map by J. Uchiyama 
401). Millets may have contributed only a relatively small part of the Neolithic diet in Korea and the Primorye (Kim, 2003; Kim et al., 2015; Miyamoto, 2014). A study of radiocarbon dates as a proxy for population size found that there was little demographic growth in Korea in the Neolithic; instead, the introduction of rice, wheat and barley in the Bronze Age was associated with a prominent surge in population (Oh et al., 2017; see also Ahn et al., 2015; Kim \& Bae, 2010).

Earlier publications, in English as well as in Japanese, discussed a number of discoveries of cereal crops from Jōmon sites but the past decade has seen a major re-evaluation of those finds (Boivin et al., 2012; Nakayama, 2010; Nasu \& Momohara, 2016; Obata, 2016) (Table 2). While recent research has shown that continental cereal crops were not introduced to Japan before the Yayoi period, it has become clear that Jōmon populations were engaged in cultivating Echinochloa crus-galli as well as adzuki and soybeans (Nakayama, 2010; Obata, 2016; Sasaki \& Noshiro, 2018). Wild soybeans (Glycine soja) were collected in Kyushu from as early as 13,000 years ago, but size changes suggesting domestication first appear in central Honshu in the Early and Middle Jōmon (Obata, 2016, pp. 23). Echinochloa crusgalli has been reported from 16 Jōmon sites in Hokkaido and two in the Tohoku and is assumed to have been cultivated, perhaps undergoing selection for domestication (Crawford, 2011). The domesticated form of this plant is Echinochloa esculenta (or utilis), commonly known as barnyard or Japanese millet. Until the twentieth century, barnyard millet was a widely cultivated cereal in Japan (e.g., Koyama, 1981). Except for barnyard millet, the earliest cultivated cereals from Japan appear to be foxtail millet from Etsuji (Fukuoka) and Ishii'iriguchi (Ōita) and rice from Itaya III (Shimane). These finds are all seed impressions on pottery from the very end of the Final Jōmon (Nakazawa, 2017). The Itaya III site produced pottery with punctuated rims, a type known from many sites in southern Korea at the same stage (cf. Kim, 2003, p. 300), including Asan Daehŭngri, Buch'ŏn Gogangdong and Ch’ŏnan Yonggoktong (see Fujio, 2015, p. 38). Apart from these discoveries, secure finds of rice, millets, barley and wheat derive from Yayoi contexts only (Nakayama, 2010). A peach kernel from the Ikiriki site, Nagasaki is said to date to around $3000 \mathrm{BC}$ and, because Prunus persica is not native to Japan, to be possible evidence of contact with the mainland (Crawford, 2011, p. 333; Naumann, 2000, p. 50). This find has not, however, been directly dated and Crawford (2011, p. 333) notes that no other examples are known from the Jōmon period. Finally, although a large number of stable isotope studies have been conducted on Late and Final Jōmon human skeletal remains, none of those studies have reported evidence of millet consumption (e.g., Kusaka et al., 2008, 2010; Roksandic et al., 1988).

One plant which may have been introduced or perhaps re-introduced into Japan in the Late-Final Jōmon is Cannabis sativa. Table 3 lists Jōmon cannabis finds based on published sources. From the Yayoi period, there are numerous archaeological examples of cannabis and hemp fibres, and the presence of flax and linen textiles in Japan is mentioned in the Wei zhi, a third-century AD Chinese history (Nunome, 1985; Hudson \& Barnes, 1991; Kidder, 2007, p. 15). In Table 3 we correct Long and colleagues' (2017, p. 247) inclusion of 'Matsugasaki and Torihama' as one site: these are two different sites and, based on the cited source (Matsui \& Kanehara, 2006), there is no evidence of cannabis from Matsugasaki. The oldest find from 


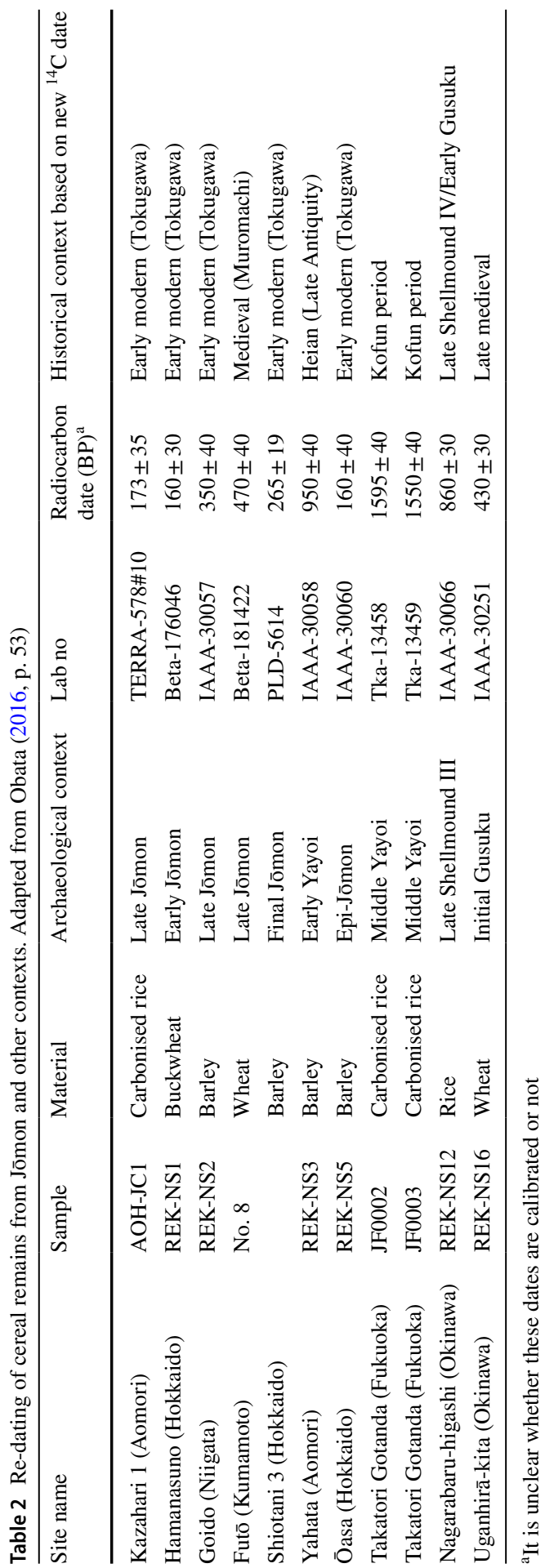




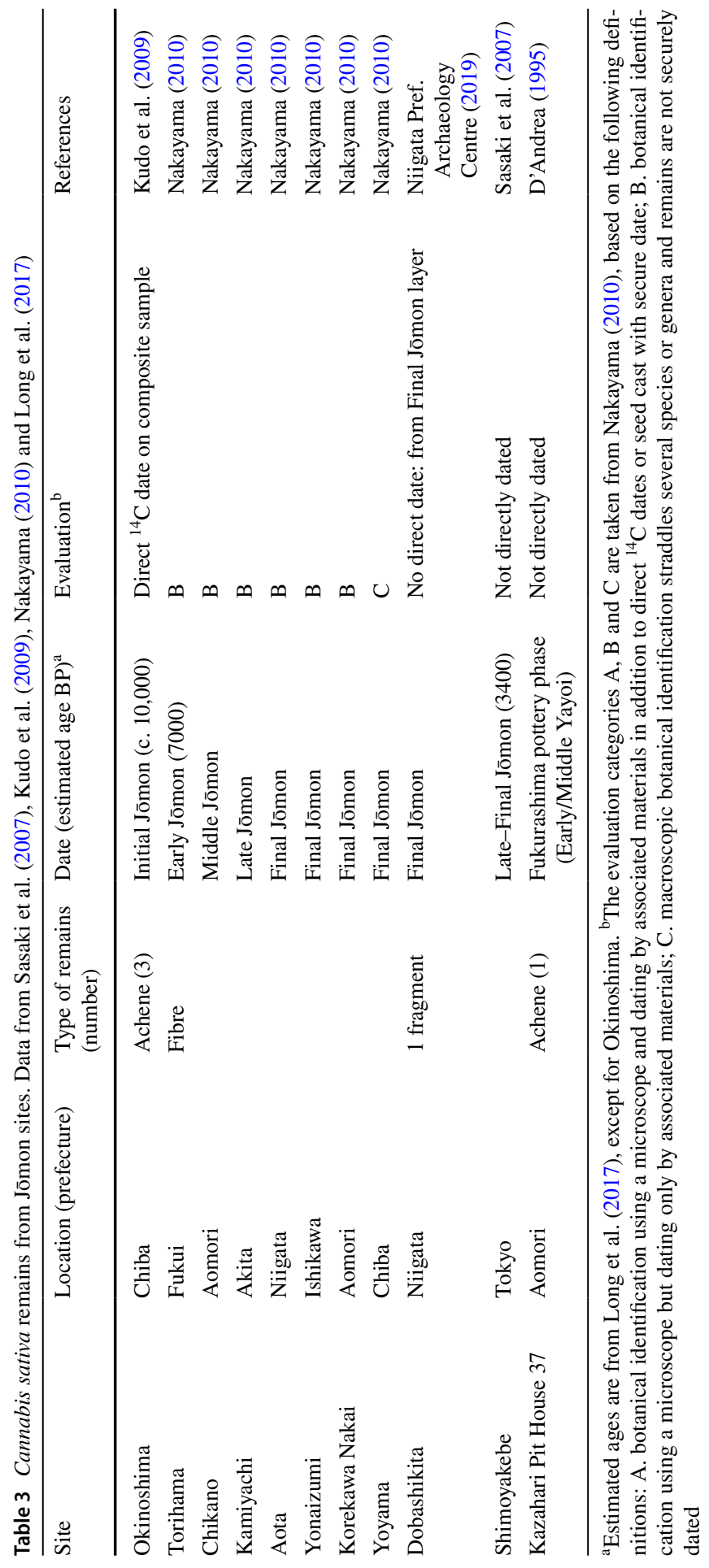


Japan is from an Initial Jōmon context at Okinoshima (Chiba), where a radiocarbon date of $8955 \pm 45$ BP (NUTA2-12,809) was obtained by combining three achene fragments to make a sample large enough for dating (Kudo et al., 2009, p. 29). Kudo and colleagues provide a calibration graph and write that the calibrated date (using Intcal04) is 'around 10,000 cal BP' (Kudo et al., 2009, p. 30). If this date is correct, it would probably be the oldest archaeological find of cannabis from anywhere in the world and would suggest that the plant was native to Japan. However, most other Jōmon cannabis finds from Japan derive from the Final phase and show dates consistent with Long and colleagues' (2017) hypothesis that cannabis took on increased importance in Bronze Age trade networks across Eurasia.

There is no evidence of the spread of domesticated animals from Eurasia to the Japanese Islands in the Middle-Final Jōmon phases. Domesticated dogs had already been introduced into the archipelago by the sixth millennium BC (Hongo, 2017). Wild boar were transported to the Izu Islands from the Initial Jōmon, and to Hokkaido from the Late Jōmon (Hongo, 2017). From the Middle Jōmon, there was an increase in boar figurines and boar burials in association with humans. aDNA analysis by Morii et al. (2002) found that one Sus sample from the Late Jōmon Miyashita shell midden in Nagasaki prefecture clustered with Asian domestic pigs. However, Morii and colleagues admit that none of their samples were directly dated, and raise other problems of interpretation which prevent us from accepting Miyashita as evidence for domesticated pigs in the Late Jōmon. Even for the Yayoi, there has been considerable debate over whether or not domesticated pigs were introduced to Japan from Bronze Age Korea (Hongo, 2017; Morii et al., 2002). In Korea itself, there is little or no evidence for domesticated pigs from the Neolithic or the Bronze Age (Lee, 2017, p. 471).

\section{Agricultural Tools}

It has been argued that narrow-waisted chipped stone 'hoes' are associated with the spread of millet farming from northeast China to Korea and the Russian Far East (Li et al., 2020; Miyamoto, 2014). Such 'hoes' are also found in Japan, first appearing at the end of the Early Jōmon in central Honshu and then gradually spreading west (Itakura, 2013; Obata, 2016, p. 26). While this timing would not rule out an influence from the continent, the location of the earliest sites with these 'hoes' does not directly support that hypothesis. Clear wooden and stone agricultural tools in Japan date from the Yayoi period (Hudson, 1990).

\section{Bronze and Bronze Skeuomorphs}

In 1954, a bronze knife was discovered at a quarry on the Sea of Japan coast of Yamagata prefecture (Fig. 3). Archaeological surveys over the following 2 years were able to reconstruct some of the circumstances of this discovery. The bronze knife is said to have come from a soil layer in Area A of the Misakiyama site. This Area A produced Jōmon pottery dating from the end of the Middle to the beginning 


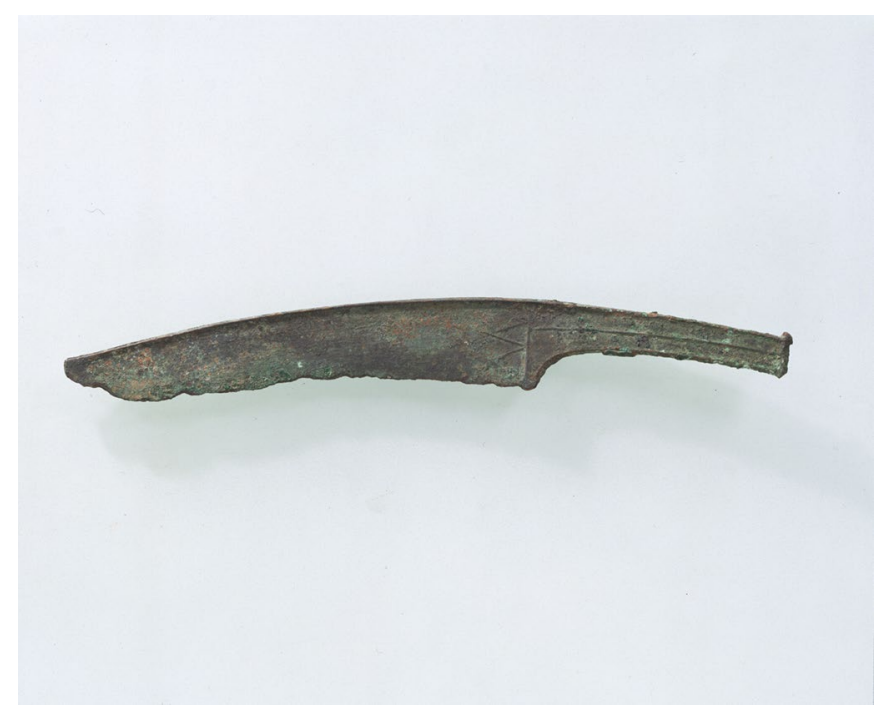

Fig. 3 The Misakiyama bronze knife. Photo courtesy of Tokyo National Museum

of the Final phases (Kashiwakura, 1961; Satō, 2000). According to Kawasaki (2002, pp. 93-4), the bronze knife was found in the same soil layer, albeit $30 \mathrm{~m}$ away, as Late Jōmon pottery, including a complete $17.6 \mathrm{~cm}$ tall pot, and some stone tools such as a fish spear and tanged arrowheads. The pot style parallels the Late Jōmon Kasori B1 and, based on the stratigraphy, it has been suggested that the knife is contemporaneous.

The Misakiyama knife has a remaining length of $26.0 \mathrm{~cm}$ and is complete except for a missing ring handle. There is no doubt that the knife itself belongs to the socalled 'Northern Bronze Complex' found in northern China, parts of the Eurasian steppe and in Shang sites in the Yellow River basin. The Misakiyama knife is typologically similar to bronze knives of the Upper Xiajiadian culture of northeast China (cf. Shelach, 2005) dated to the eighth to third centuries BC (Northeast Asian History Foundation, 2007). A lead isotope analysis by Hirao et al. (2001) found that the materials used to make the Misakiyama knife were similar to those of the Late Shang (Ichikawa, 2013, p. 46). Kashiwakura (1961) raised the possibility that the knife had been brought back from China, perhaps after the Second World War, and somehow planted at Misakiyama. While that possibility cannot be completely ruled out, the find is accepted as genuine by most Japanese scholars (Nakayama, 1992; Satō, 2000; Kawasaki 2002; Matsugi, 2007, p. 174).

Although the bronze knife from Misakiyama is the only metal artefact known from the Jōmon period, it has been widely argued that certain types of stone (and, more rarely, bone) 'swords' and 'knives' known from the Late and Final phases were made as skeuomorphs of bronze tools (Fig. 4). Stone copies of metal tools were extremely common in the Bronze and Iron Ages of continental northeast Asia (Shoda et al., 2009; Tabarev, 2014; Yanshina \& Shoda, 2014). Japanese archaeologists distinguish between doubled-edged stone swords (sekken) and single-edged stone knives (sekitō) (Habu, 

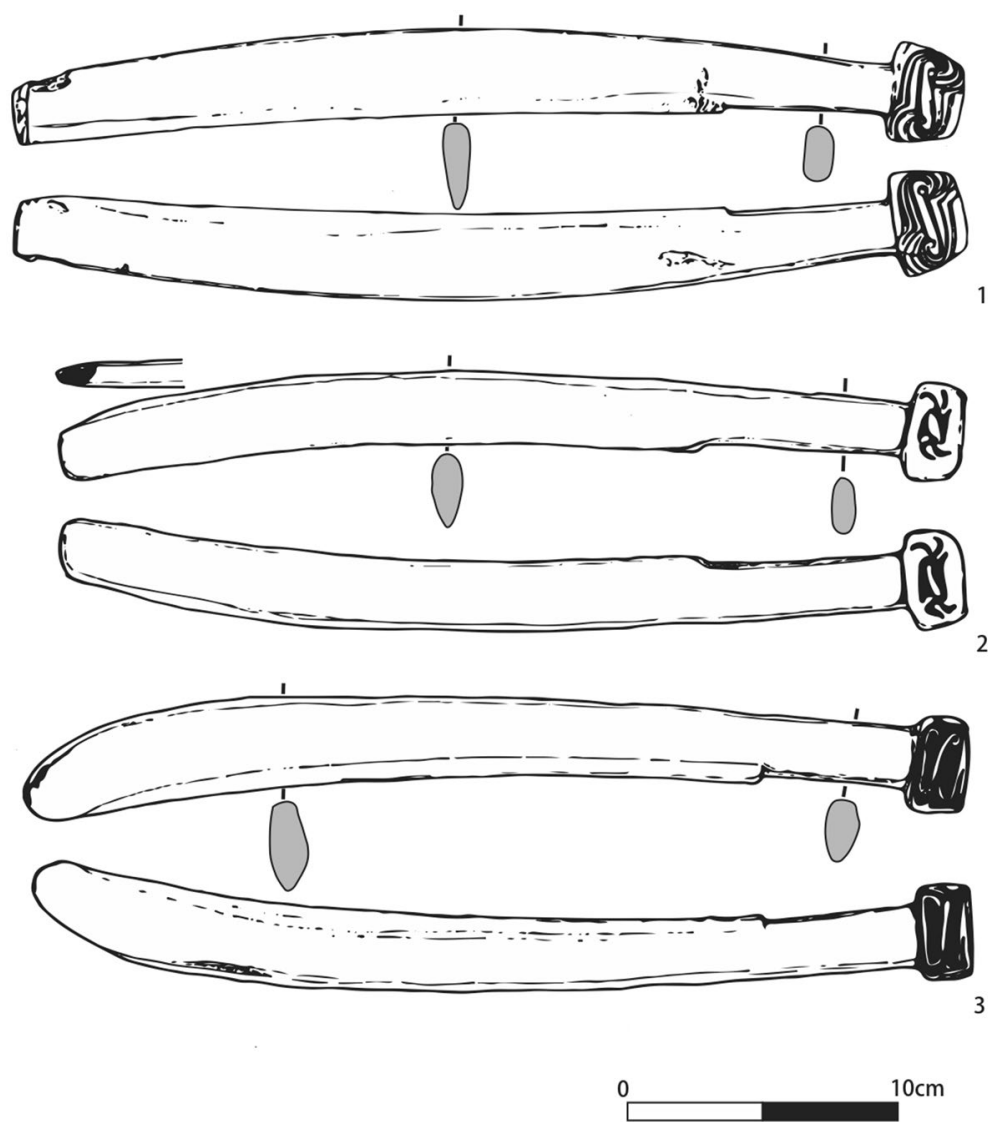

Fig. 4 Jōmon stone knives made in probable imitation of northern bronze knives such as Fig. 3. Redrawn from Nomura (1985) by J. Uchiyama

2004, p. 153). Though some researchers believe that these objects may have developed from phallic stone rods (sekibo), others have argued for an influence from north Chinese bronze daggers (Kita, 1926; Esaka, 1965; Nomura, 1985; Nishiwaki, 1998; cf. Habu, 2004, p. 153). These stone swords/knives usually have carved knobs and the design of those knobs may also have been influenced by Eurasian bronze prototypes (Nishiwaki, 2008).

Jōmon stone objects of a mysterious type with broad blades are known as seiryūtō or 'green dragon swords' because of their superficial resemblance to much later Chinese weapons. Such objects were illustrated by several European scholars in the late nineteenth century (Siebold, 1879; Milne, 1881, Plate XVIII, No. 17). According to Nomura (1985), these objects date from the Middle Jōmon and may thus be too early to have been based on metal prototypes, but Doi (1992a) writes that it is 'generally assumed ... that the prototype came either from the Asian continent or the North Pacific.' 


\section{The Itoku Site}

Other possible evidence for metal use in the Final Jōmon has been reported from the Itoku site on the Pacific coast of Shikoku. According to Matsui (2005), both animal and human bones from a deposit dated to 3200-2800 BP have modifications consistent with the use of metal knives or swords. As the same site has also produced Chinese lacquer ware (see below), it has been claimed that these observations and artefacts can reasonably be interpreted as evidence that metal-using foreign invaders reached Jomon Japan' (Bleed \& Matsui, 2010, p. 360). While this interpretation would be consistent with the overall approach adopted in this paper, a recent re-examination of the human bones from Itoku by one of the present authors (J.A.W.) concluded that the preservation was too poor to confirm traumatic lesions. The taphonomic mineral reactions in the cortical bone especially make it difficult to determine the cause(s) of the observed deformations. Furthermore, the linear marks and fractures present lack the diagnostic characteristics of cut marks from either stone or metal implements such as clear fracture edges, V-shaped crosssections, internal micro-striations and Hertzian fracture cones (cf. Fernández-Jalvo and Andrews, 2016; Villa \& Mahieu, 1991; Lyman, 1994). The traumatic injuries reported by Matsui that were not attributed to metal weaponry appear more consistent with taphonomic damage, such as paired dental marks by carnivore scavengers (Fig. 5). Our re-analysis of the human bones does not, therefore, support the use of metal at Itoku, suggesting the need for further evaluation of the animal bones from the same site which Matsui (2005) also reported as having cut marks from metal blades.

The Itoku site also produced a lacquerware artefact. Made from wood of a camphor tree (Cinnamomum camphora), this object is believed to be part of a lid and has a complex 'curly cloud' geometric design painted in black and red lacquer (Fig. 6). It was discovered in a layer with Late and, especially, Final Jōmon pottery. Bleed and Matsui (2010) suggest this lid originated in southern China in the first millennium BC. By the Eastern Zhou period (771-256 BC), lacquerware was widely used in both North and South China (Wu, 2011). The Itoku lid may have come from either the Shandong peninsula or the Yangtze River valley, areas both well known for Eastern Zhou lacquerware. Both Shandong and Yangtze lacquerware had thunder or cloud patterns during this period, but curly cloud patterns are characteristic of the latter region. The curly cloud patterns of the Itoku lid therefore suggest a south China (Yangtze) origin.

\section{Stone Axes}

A rectangular, perforated stone axe made of serpentine from the Nakagawadai site (Yamagata) is $12.5 \mathrm{~cm}$ long, $7.6 \mathrm{~cm}$ wide and $1 \mathrm{~cm}$ thick (Naumann, 2000, p. 52) (Fig. 7). The axe was found in 1966 when the site was being excavated by the history club of a local middle school and was said to be associated with Middle Jōmon pottery (Satō, 2000). An incised mark on this axe resembles a Chinese character and may be related to the oracle 

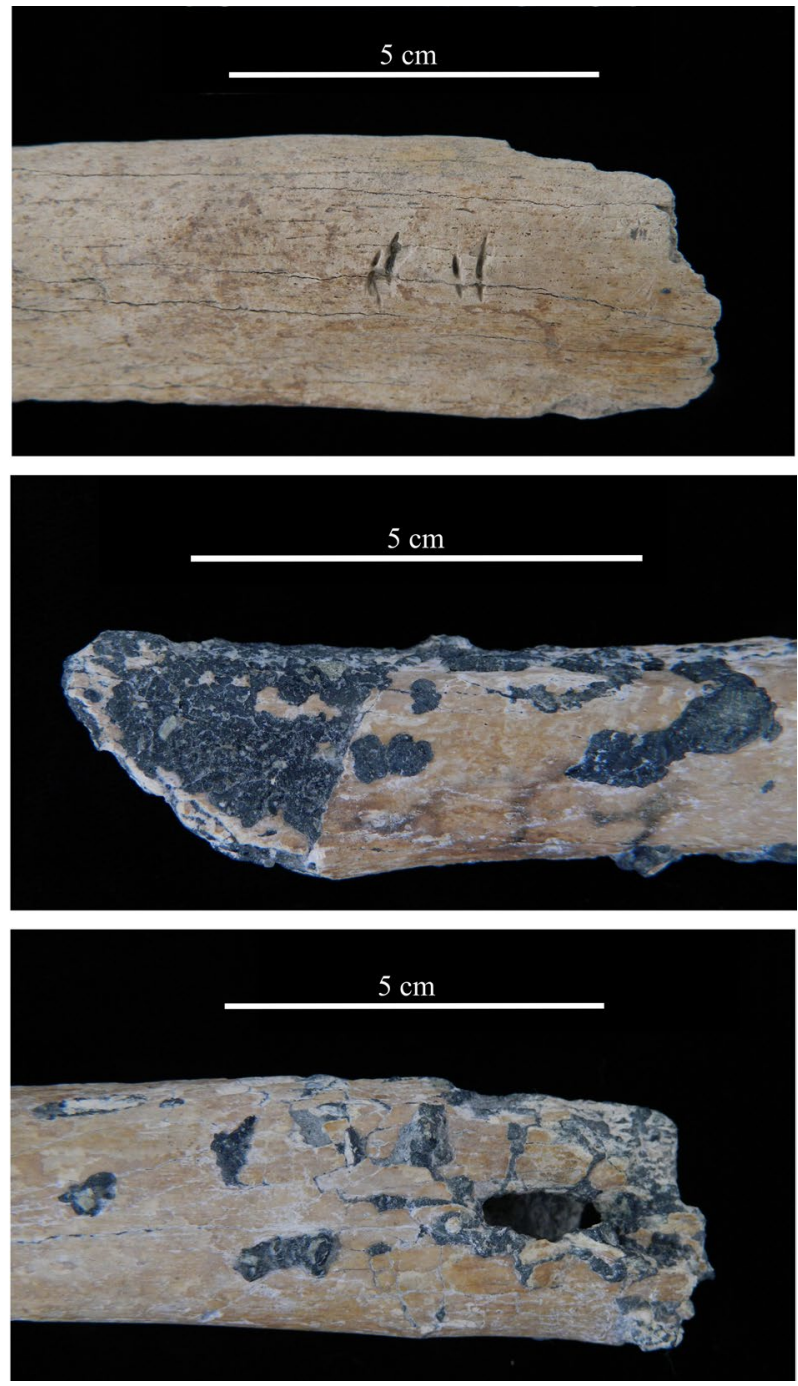

Fig. 5 Human bones from the Itoku site with lesions described (in parentheses here) as traumatic in aetiology by Matsui (2005). Top: J004, right femur ('stab wound'); Centre: J002, proximal left femur ('bladed weapon cut'); Bottom: J002, distal left femur ('penetrating trauma'). Photos: J. A. White

bone character sheng, meaning 'to grow' or 'bring forth'. This type of perforated axe is common in Neolithic China (cf. Barnes, 2015, p. 158), but according to Naumann (2000, p. 52), 'no stone axe with incised characters has been found in China proper, and the same holds true for the coating of the axe with chalk.' Rectangular axes with perforations are also found in the Bronze Age and there are certainly bronze examples with inscriptions (e.g., Bagley, 2004, p. 205). Kawasaki (2002, pp. 97-98) has argued that the 'character' was incised with a metal tool, but this needs to be confirmed with microscopic analysis. 

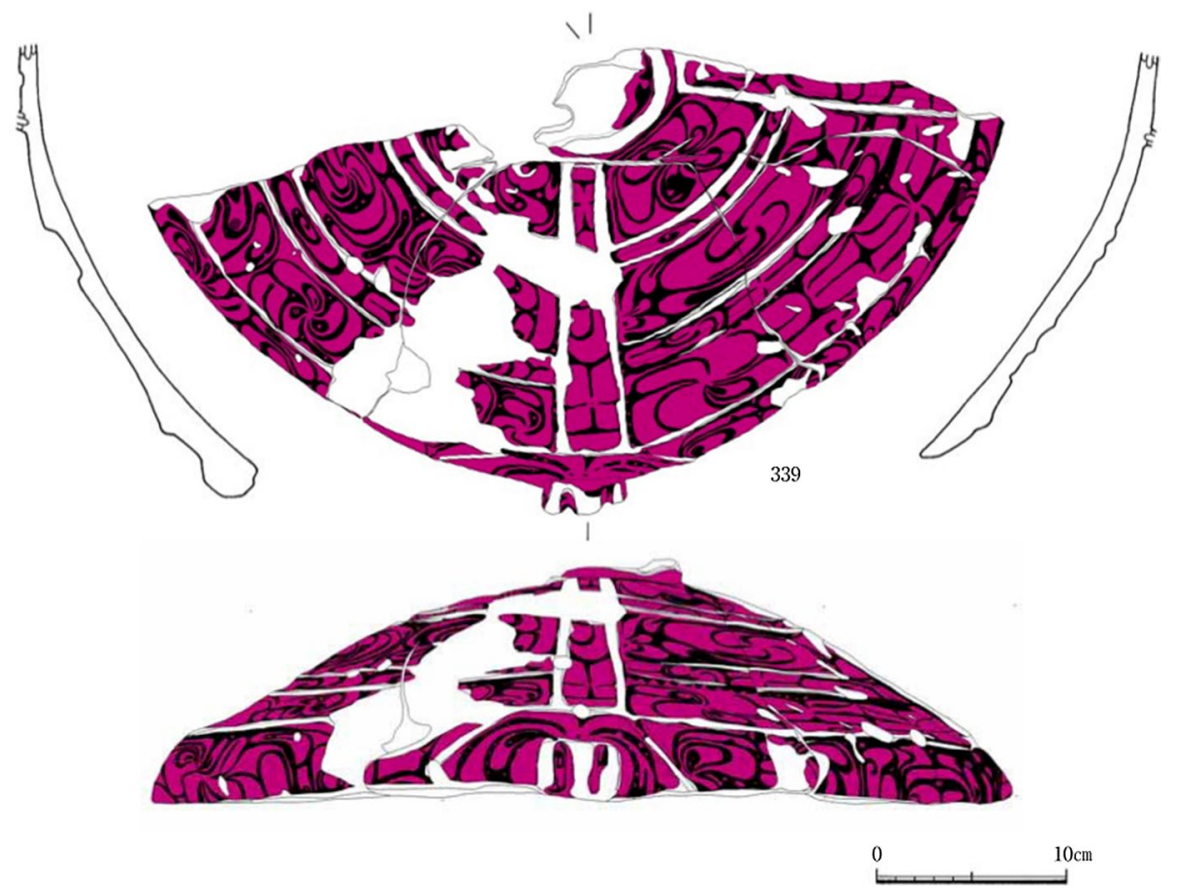

Fig. 6 Wooden lid with lacquer, Itoku site. From Kōchi-ken (2003)
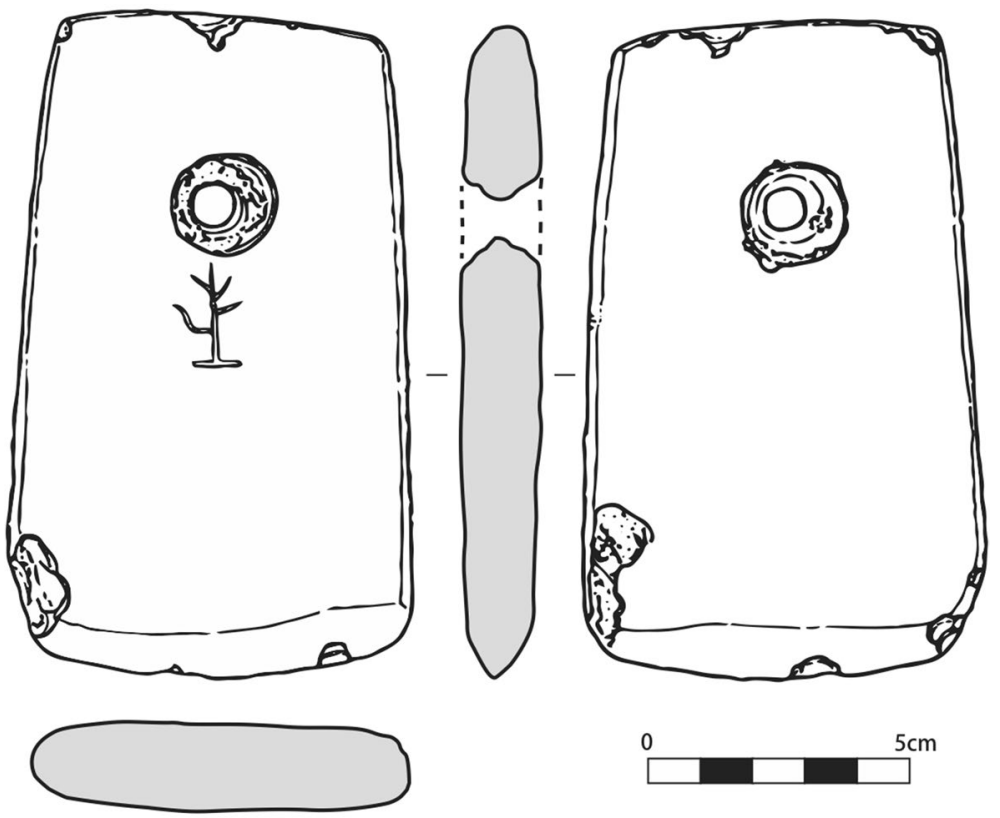

Fig. 7 Stone axe from Nakagawadai. Re-drawn from Satō (2000) by J. Uchiyama 
Three possible interpretations of the Nakagawadai axe seem to present themselves. The first is that it was imported from China with the 'character' already incised. The second possibility is that the axe itself came from China but the 'character' was added later in Japan. Finally, it is possible that the axe was made in Japan where the 'character' was also incised. Of these three, the first seems unlikely because of the lack of similar finds in China. Both the second and third interpretations assume that the Jomon people were aware of and attempted to imitate early Chinese writing. If the symbol on the Nakagawadai axe does represent an early Chinese character, and if the symbol was incised with a metal tool, then that incision is unlikely to date from before the Bronze Age.

Several other Jōmon sites have produced polished axes which may directly imitate bronze artefacts. The best-known such site is Uwahaba (Akita) where four large axes ranging from 60.2 to $32.0 \mathrm{~cm}$ in length were found during construction work in 1965 (Shōnai, 1999). An emergency survey was organised a week later and test excavations were conducted in 1998. The pottery found in these excavations is said to date from the Early Jōmon (Shōnai, 1999; Kobayashi, 2013), implying an age of 7500-5500 years ago, but the pottery was not found in direct association with the axes (Harada, 1992). At least two of these axes display attributes that have been linked with bronze artefacts (Kobayashi, 2013). One axe has a central ridge reminiscent of bronze casting techniques, and a second has a side groove which appears more consistent with metal-working than with lithic technologies. The fact that these four axes were found buried together in an apparent 'hoard' has also suggested Bronze Age comparisons to Japanese archaeologists. Unfortunately, the exact date and context of the Uwahaba axes and several similar finds discussed by Yamanouchi (1972) and Kobayashi (2013) remain uncertain.

\section{Pottery}

The Late and Final phases were marked by two major changes in Jōmon ceramics (Habu, 2004, pp. 203-209). First, there was a notable increase in the variety of vessel forms, with shallow bowls and spouted vessels becoming more common (Table 4). Second, there was a clear differentiation between coarse and fine wares. In eastern Japan, most archaeologists regard these as internal changes within Jōmon society (Habu, 2004, p. 208). In western Japan, in contrast, it has been widely argued that a trend towards minimal decoration in Late-Final pottery was an influence from

Table 4 Frequency of ceramic vessel shapes over the Jōmon period

\begin{tabular}{|c|c|c|c|c|c|c|}
\hline & Incipient & Initial & Early & Middle & Late & Final \\
\hline Deep bowl (fukabachi) & (2) & (2) & (2) & (2) & (2) & (2) \\
\hline Shallow bowl (asabachi) & & & $\bigcirc$ & $\bigcirc$ & $\bigcirc$ & O \\
\hline Spouted vessels & & & & & $\bigcirc$ & $\bigcirc$ \\
\hline Jars (tsubo) & & & & & & $\bigcirc$ \\
\hline Pedestalled vessels & & & & & & $\bigcirc$ \\
\hline
\end{tabular}

(): common, $\bigcirc$ : present. Adapted from Matsumoto (2018b, p. 114) 
the Korean peninsula or even from China. In Kyushu, a type of black-burnished Final Jōmon pottery has previously been linked with Longshan wares of Late Neolithic China. With its black, polished walls and carinated shapes, this pottery 'is radically different [from other Jōmon ceramics], looking as though an effort was made to simulate metal' (Kidder, 1993, p. 74; see also 1957, p. 150). Remarkably similar techniques were used in Bronze Age cultures in western Eurasia. At the Monte Polizzo site on Sicily, for example, 'the semi-lustrous surface and sharply carinated form of bowls evoke metal objects (Dixon, 2004), implying a transfer of prestige from a highly valued medium to another material' (Sofaer, 2010, p. 213). Wheelthrown Longshan blackwares are finely made ceramics dating to c. 3000-2000 BC, which have a long history of being linked with distant cultures (e.g., Heine-Geldern, 1959). While we are not suggesting a direct link between the Jomon and Longshan, let alone with Bronze Age Sicily, there is a possibility of similar processes of imitation at work in Final Jōmon ceramics.

A clearer case of imitation is a three-legged jar excavated from a Final Jōmon layer at Imazu (Aomori). The jar has cord-marking and red paint and is thought to belong to the Öbora $\mathrm{C}_{2}$ type of the Final phase (Shintani \& Okada, 1986) (Fig. 8). Radiocarbon dates on charred material on the inner surface of sherds of the same ceramic type from Imazu have produced results of 3125 20 (PLD-16567) and $3110 \pm 20$ (PLD-16568) BP. These figures were calibrated using the RHCcal $3.3 \mathrm{~s}$ programme (Imamura, 2007) to derive $1 \sigma$ dates of 1430-1396 and 1419-1383 cal $\mathrm{BC}$, respectively, dates which may be older than their absolute age due to a marine reservoir effect (Horiuchi et al., 2015). A direct connection with long-distance trade
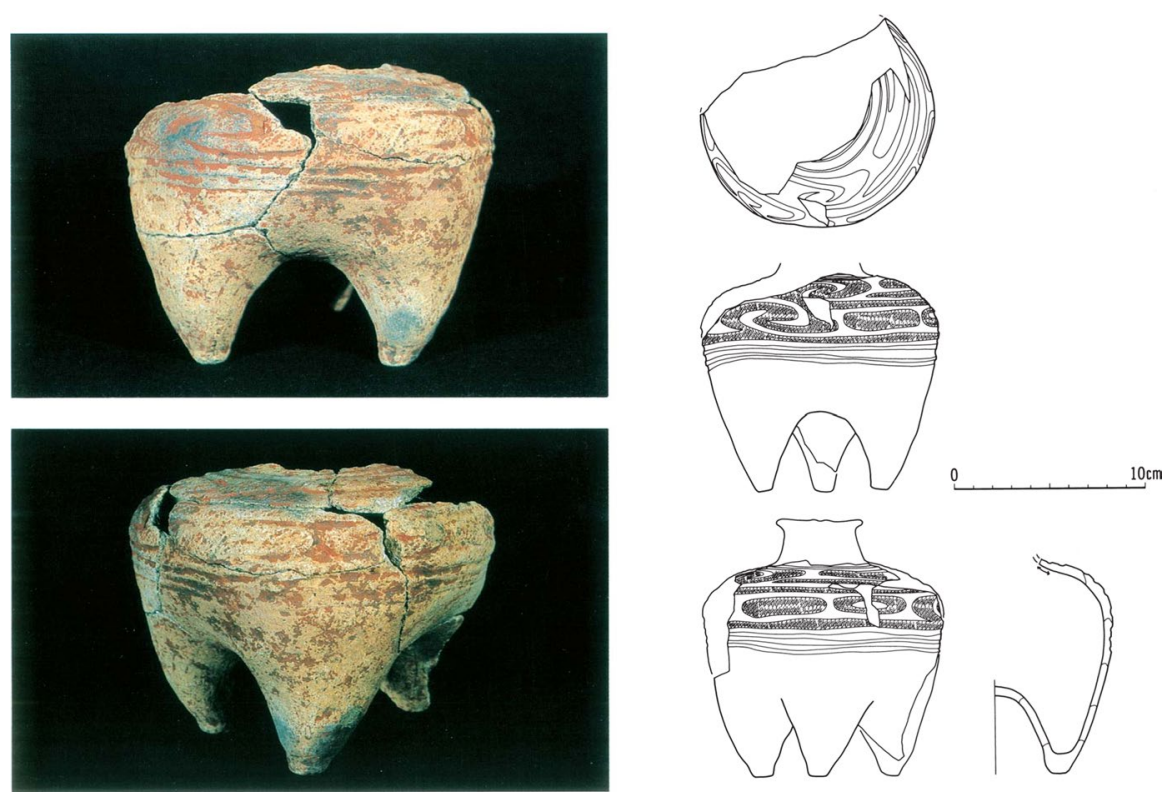

Fig. 8 Final Jōmon tripod from the Imazu site: Courtesy of Aomori Prefecture Archaeology Research Centre 
is suggested by the fact that the Imazu site has produced salt-making pottery (Horiuchi et al., 2015). Three more tripods from the same period found at sites in Aomori (Tominosawa, Kurosūda and Kokūzō) may similarly have been influenced by continental Bronze Age contacts (Kikuchi et al., 1996; Kawasaki, 2002; An, 2002). Another tripod from the Goshono site in Iwate is illustrated by Matsumoto (2005, p. 35). The main occupation layers at Goshono date to the late Middle Jōmon but we are unsure if this tripod can be securely assigned to such an early date. A Late Jōmon vessel with four small feet from Shiizuka (Ibaraki) illustrated by Kenrick (1995, p. 119) may be an attempt to imitate the tripod form. Vessels of the same shape as the Imazu vessel are found in northern China after about 2500 BC and are termed 'baggy-legged tripods' by Wagner and Tarasov (2014). Hollow-footed tripodal vessels appear to originate in the Dawenkou culture in Shandong, spreading to the middle Yellow River basin by the early third millennium BC (Zhang, 1999). Nelson (1999, p. 161) emphasises that while tripods were ubiquitous in China by 2000 BC, they are absent from Korea, suggesting this reflects a rejection of central Chinese culinary and ritual traditions in the Korean Bronze Age. In China, tripods were most widely used in the middle and lower reaches of the Yellow River valley but are less frequent on the Liaodong peninsula (Wang \& Piao, 2016, p. 10). This may suggest that tripods became less common as they moved northeast. While the route of transmission of such vessels to Jōmon Japan is unclear, An (1991) regards the Imazu tripod as a direct imitation of a Chinese vessel.

A further category of Jomon pottery that can be related to the continent is the spouted vessel. Although one bowl with a spout is known from the Incipient Jomon Muroya site (Niigata), that 'spout' is more or less flush with the outer surface (Doi, 1992b). According to Kenrick (1995, p. 97), the first projecting spout appears in the Early Jōmon but such vessels become much more common and take on the classic 'teapot' shape from the Late Jōmon (Fig. 9). It is widely accepted that these vessels reflect a continental influence (Barnes, 2015, p. 282). Aikens (2012, p. 59) argues that Late and Final phase "cultural luxury items-for example, burnished pottery

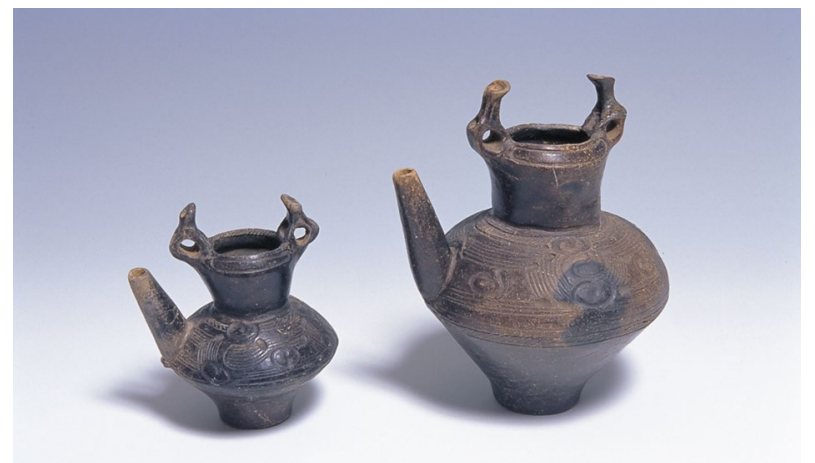

Fig. 9 Black-burnished spouted vessels from the Imai Higashidaira site (Gunma). Kasori B phase, Late Jōmon. Courtesy of Tsumagoi History Museum 
wares and spouted and handled ceramic teapots-reflect a growing awareness of distant continental cultures and practices.'

\section{Ritual Contacts}

From the Middle phase onwards, Jōmon culture saw a remarkable increase in archaeological remains relating to ritual behaviour. Clay figurines, for example, are known from the Incipient phase but become much more common from the Middle Jomon (Bausch, 2010b; Habu, 2004, pp. 144-151). Until the Middle phase, such figurines had only been found as far west as Shiga prefecture, but from the Late Jōmon they are found across west Japan, except for Okinawa (Matsumoto, 2005, p. 153). At least 30 clay masks (or fragments) are known from Late and Final Jōmon sites, mainly in the Tohoku area (Habu, 2004, p. 155). Matsumoto (2011) argues that the Late-Final Jōmon distribution of eastern Japan-made jadeite beads in Kyushu and Okinawa was mirrored by the eastward expansion of Kyushu-made tubular greenstone beads, which found their way to western Honshu sites as distant as Nishida in Gifu. A large quantity and variety of polished stone rods are also associated with the Middle-Final phases (Habu, 2004, pp. 151-155). Although earlier generations of archaeologists saw close links between Late-Final Jōmon stone circles and monuments from northeast China and Siberia (e.g., Komoto, 1982), clear evidence of such a link is lacking. Dolmens from the Korean peninsula do spread to northwest Kyushu at the beginning of the Yayoi period but they are often associated with native Jōmon skeletal remains and isotope analyses of those remains suggests a continuing dependence on marine foods rather than agricultural crops (Mihara et al., 2004).

Although the possibility of earlier examples has been raised, the first uncontroversial ritual tooth ablation in Japan dates from the end of the Middle Jōmon. This custom then flourished during the Late and Final phases and into the Yayoi (Han \& Nakahashi, 1996; Nakahashi, 1999). The widespread distribution of tooth ablation in Japan at this time is shown by its presence at the Late Jōmon Funadomari site on Rebun Island, Hokkaido (Matsumura et al., 2001). Forked teeth filing is also known at some sites around Nagoya (Harunari, 1986). Tooth ablation is known in Shandong and coastal areas of northeast China from around 5400 BC. Research comparing tooth ablation patterns at Yayoi sites, such as Doigahama, with Neolithic sites of the Shandong region in northern China, such as Dawenkou, shows basic similarities in the age at commencement of ablation (approximately 12-15 years) and in the prevalence of the extraction of upper lateral incisors (Han \& Nakahashi, 1996, pp. 49-50). The adoption of this custom in Jōmon society can be argued to represent a major change since it must have been traumatic for those undergoing the tooth removals (Takenaka et al., 2001). If this custom was indeed introduced from, or influenced by, China, then it seems likely that it derived prestige from its 'international' identifications. A parallel here might be with the standardised filed front teeth possessed by some Viking men (cf. Arcini, 2005, 2007). A common interpretation of Jomon tooth ablation - that it was related to coming-of-age ceremonies and post-marital residence patterns (Harunari, 1986) - is not supported by recent research, which suggests a connection with lineage-based subsistence procurement groups (Kusaka et al., 2008; Temple et al., 2011). Mizoguchi (2017, p. 539) 
suggests that in the Late Jōmon, the difficulties of maintaining 'intra- and inter-communal collaboration and negotiations over limited and shrinking resource bases' might have resulted in 'signifiers inscribed on the body in the form of ritual tooth extraction bec[oming] necessary as a medium with which to give orders to the world.'

\section{Linguistic Interaction}

A final category of interaction between Jōmon Japan and the East Asian mainland during the period considered here is linguistic. Given the archaeological connections outlined above, some language contact-perhaps including the borrowing of loan words for new objects and ideas-almost certainly occurred. Language contact with coastal China is also a possibility at this time but actual linguistic evidence suggests that contact with the Korean peninsula was more extensive.

Although the question of whether Japanese and Korean are related to the Tungusic, Mongolic and Turkic languages is still debated, the genealogical relationship between Japanese and Korean is gaining acceptance among linguists (Whitman, 1985; Unger, 2009; Ratté, 2016). Proto-Japonic, the ancestor of Mainland Japanese and the Ryukyuan languages, has been associated with the language of the immigrants who established Yayoi culture on the Japanese Islands (Hudson, 1999; Whitman, 2012). By contrast, proto-Koreanic, the ancestor of the contemporary Korean dialects, Middle Korean, as well as some fragmentary recorded historical languages, such as those of Silla and Paekche, can be viewed as the language of the farmers who brought millet agriculture to Korea (Robbeets, 2017) (Fig. 2). From this perspective, the separation of proto Japano-Koreanic into Japonic and Koreanic probably occurred on the Liaodong peninsula in northeast China between 3500 and 2000 BC (Robbeets, 2017).

Ainu and Nivkh have been regarded as marginal pockets of earlier language types whose lineages became isolated at the time of the expansion of Japonic, Koreanic and other Transeurasian languages (Fortescue, 2013; Nichols, 2011). Ainuic, the language ancestral to Ainu, has been associated with one of the indigenous languages spoken by Jōmon populations (Hudson, 1999; Vovin, 1993, p. 190). Indeed, linguistic evidence suggests a language shift whereby some of the ancestral speakers of Ainu abandoned their native language and adopted proto-Japonic as a new target language, whereas speakers of ancestral Nivkh replaced their native language with proto-Koreanic. This evidence comes from atypical structural features in Japanese and Korean that are likely to have developed through substratum interference from pre-Ainu and pre-Nivkh, respectively (Robbeets, 2017). Among others, these features include-for Korean - the occurrence of initial consonant clusters, two distinctive tones and three laryngeal contrast sets and-for Japanese-the distinction between intentional and non-intentional action in certain verb affixes, productive noun-incorporation, and the occurrence of prefixing morphology in spite of being verb-final. Even if Korean shares these structural parallels with Nivkh, implying language shift, there are no lexical parallels between the two languages, implying mutual loanwords (Janhunen, 2016). 
Nevertheless, we find some lexical lookalikes between Ainu and Korean, which are suggestive of prehistoric language contact between the ancestral speakers of the two languages. (The following abbreviations are used in this section: J: Japanese; K: Korean, OJ: Old Japanese; pA: proto-Ainuic; pK: proto-Koreanic.) Such potential loanwords include terms for natural landmarks such as (1) K na:y 'river' and Ainu náy 'river, stream'; (2) K yem 'small stony island, small rocks sticking out of the water' and Ainu yá 'dry land (as opposed to sea), shore, high rock'; words for housing and locality such as (3) K aph 'front, fore part' and Ainu apá 'doorway, entrance'; (4) K kot 'place, locality, site' and Ainu kotán 'village, town, country, place'; terms for fauna such as (5) K say 'bird' and Ainu say 'flock, flight of birds'; terms relating to the body such as (6) K nwun 'eye' and Ainu núu 'eye'; (7) K ni 'tooth' and Ainu nii 'tooth'; (8) K alh- 'suffer from' and Ainu árka 'painful, sore, hurting'; words for food production such as (9) K a:m 'hot cereal; thick rice soup' and Ainu amám 'cereals, rice'; and (10) K swi:- 'to turn sour, spoil (intr.)' and Ainu síw 'to be bitter'. See the supplementary information for a detailed description of these etymologies.

Most of these lookalikes are nouns and belong to the cultural vocabulary, which is suggestive of borrowing in a sporadic to moderate contact setting (Thomason \& Kaufman, 1988). Even if body part terms are usually considered as basic vocabulary, it may be possible to interpret the borrowing of 'tooth' and 'eye' within the cultural context of ritual tooth ablation. The direction of the borrowing seems to be from ancestral Koreanic into ancestral Ainuic, because some Korean forms have a broader meaning (e.g., (5) K 'bird' vs. Ainu 'flight of birds'); they preserve primary or less cultural meanings (e.g., (3) K 'fore part, front' vs. Ainu 'doorway, entrance'; (4) K 'place, locality, site' vs. Ainu 'village, town'); they are morphologically complex (e.g., (8) pK *alk-a (suffer.from-FIN) 'suffers from' $\rightarrow \mathrm{pA} *$ árka 'painful'); the phonological correlation supports the directionality (e.g. (3) $\mathrm{pK} *-l p$ - in *alp - $k$ 'fore part, front' is imitated as $\mathrm{pA} *-p$ - in $\mathrm{pA} * a p a$ 'doorway, entrance'); two synonymous basic vocabulary items coexist in Ainu (e.g., (6) pA *núu 'eye' and pA *sík 'eye'; (7) pA *nii 'tooth' and pA *imak 'tooth'); or they have a Japanese cognate supporting their originality (e.g., K yem 'small stony island, small rocks sticking out of the water' is cognate to J yama 'mountain'). The direction of the borrowing implies that the speakers of Koreanic were technologically superior or socially more prestigious than the speakers of Ainuic.

It is not possible to pinpoint the exact time of these borrowings, but there are indications of upper and lower limits. Parallels such as K a:m 'hot cereal; thick rice soup' and Ainu amam 'cereal grain or rice' suggest that the borrowing occurred later than the introduction of cereal cultivation to the Korean pensinsula (i.e. after $3500 \mathrm{BC}$ ) and probably after the introduction of rice cultivation (i.e. after 1500 BC). Most Korean-Ainu lookalikes described above lack a potential Japanese parallel, and if there is a Japanese cognate (e.g. J yama 'mountain'), the Ainu forms are semantically or formally closer to the Korean lookalike than to its Japanese cognate. This suggests that the contacts between Koreanic and Ainuic speakers took place after the separation between Japonic and Koreanic (i.e. after 2000 BC) and without intermediary Japonic speakers. As far as the upper time limit is concerned, the contacts must pre-date the Ainu migration to Sakhalin in the thirteenth century AD 
(Hudson, 2017) because the Ainu words have cognates in Sakhalin Ainu. Moreover, they pre-date the time of the Old Japanese Manyōshū poetry (i.e., AD 500-759) because some of the Ainu loanwords have in turn been transmitted into Old Japanese (e.g. (1) Ainu náy 'river' $\rightarrow$ OJ na 'river'; (2) Ainu yá 'dry land, shore' $\rightarrow$ OJ $y a$ 'shore'). The relative lack of Japanese intermediate loans suggests that the Ainuic and Koreanic speakers were in direct contact, probably at a time before the spread of Japonic speakers over the Japanese Islands (i.e., before 200 BC). Therefore, the prehistoric contact between Koreanic and Ainuic speakers presumably took place on the Japanese archipelago between 1500 and 200 BC, in Late-Final Jōmon contexts.

Using Heggarty's (2007) proposal that Quechua formed a lingua franca for the Inca empire, Jennings (2011, p. 129) suggests that one feature of ancient globalisations might be the development of such bridge languages. Here, however, we do not find any evidence for a Jōmon lingua franca as the limited body of around ten potential borrowings from Koreanic into Ainuic only implies low to moderate contact between ancestral speakers of Korean and Ainu. Given the limited intensity of the contacts (mainly nouns, some inflected verb forms, plus cultural vocabulary) and the cultural sphere of the vocabulary, it is more parsimonious to see these borrowings within a restricted context of trade and cultural exchange. We hypothesise that some Late-Final Jōmon Ainuic speakers, familiarising themselves with Koreanic for the purpose of cultural exchange and trade, were responsible for introducing Koreanic words into Ainuic.

\section{Discussion}

Interaction between Jōmon Japan and the Eurasian mainland had occurred since the beginning of the Jommon period and indeed from the Palaeolithic before that, but the Late-Final Jōmon phases saw an increase in the diversity of objects and, presumably, of ideas which reached Japan. Geographically, it is not the case that all of these objects first entered Jōmon Japan through Kyushu or Hokkaido, the islands closest to the mainland. Given known ocean currents around Japan, several of the examples summarised above-including finds from northeast Honshu or southern Shikokumight reflect drift or accidental voyages from the mainland (cf. Im, 1995). For reference it might be useful here to cite a Second World War plan to float fuel and food to Japan only using ocean currents. This plan was developed after Japanese scientists found that $90 \%$ of bottles set adrift on the east coast of Korea reached the northern coast of Honshu (Tsutsui, 2003, pp. 303-304). While some voyages to Japan were no doubt accidental, however, several of the objects discussed above can be considered as prestige goods, suggesting more structured patterns of interaction. The Korea Straits were probably the main focal point of exchange networks between Japan and the continent in the latter half of the Jōmon (Bausch, 2016; Miyamoto, 2008). However, Bausch's previous work found that there was no progressive increase in connectivity over time. Korea Strait interaction declined in the Middle Jōmon but then reached its peak from the end of the Middle into the Late phases (Bausch, 2016, pp. 425-426). In the second half of the Late Jommon, the network focus shifted to eastern Japan (Matsumoto, 2005). 
Kobayashi (1992) suggested that 'new information' from the Korean peninsula in the Late Jōmon led to a 'conservative' strengthening of Jōmon traditions as part of a 'resistance movement' to the new cultural influences. Here, however, we have argued that the Late-Final social changes represent a much more complex phenomenon, which involved both 'traditional' and radically new manifestations. Furthermore, as noted by Teramae (2017, pp. 53-54), eastern Jōmon cultural traits cannot be seen as 'traditional' in the west of the archipelago: for Late-Final Jōmon people living in Kyushu, eastern style clay figurines and stone rods represented a 'foreign' cultural incursion. More broadly, the evidence for Middle-Final Jōmon interaction between Japan and the continent discussed here suggests a rather different pattern from that proposed for forager/farmer frontiers in Europe (cf. Zvelebil \& RowleyConwy, 1984). The later Jōmon did not see the patterned exchange of raw materials and goods found in the Mesolithic-Neolithic transition in northern Europe (Zvelebil, 2008). The types of interaction described above are also not consistent with interpretations of the forager to farmer transition made by many Japanese archaeologists, who assume that rice or other cereal crops would be quickly adopted once available. Kondō (1962), for example, proposed that a relative paucity of natural resources in western Japan led to a generalised subsistence adaptation which easily adopted rice agriculture when it became available. Eastern Jōmon populations, in contrast, were argued to have been more specialised, and scheduling and other demands made it harder for them to adopt farming (Akazawa, 1982, 1986, 1988). Recent research suggests that an expansion in the cultivation of legumes in the western Jomon was not mirrored by the adoption of millet from the Korean peninsula as predicted by Kondō and Akazawa. Late-Final Jōmon societies did, however, develop a concern with long-distance connections and appear to have imitated several types of material culture from Bronze Age Eurasia, including stone 'swords' based on metal prototypes, black-burnished pottery which may have been influenced by metal vessels, and pottery tripods. These objects were probably not made in isolation but suggest conscious relationships between different craft activities (cf. Sofaer, 2010). There was also an increase in mobility, especially maritime mobility from the Late Jōmon phase.

The Late-Final Jōmon 'accommodation to the foreign' has parallels with western Eurasia in the Bronze Age (cf. Kristiansen and Larsson, 2005). The extent to which Japan can be said to have been part of a Bronze Age world system is, however, unclear. There is considerable evidence for trade and exchange within Japan during this period but, with some exceptions, the possibility of trading contacts with the mainland has rarely been discussed (Bausch, 2016). The specialist craft production found in the Late-Final Jōmon included ceramics, shell beads, jadeite ornaments, greenstone beads, polished stone axes, lacquerware and salt (Kinoshita, 2003; Bausch, 2004, 2010; Sakaguchi, 2011; Kawashima, 2015b; Matsumoto, 2011, 2018a). The existence of very long-distance networks at this time is clear and Final Jōmon Kamegaoka pottery from the Tohoku region is found as far south as Okinawa (Shitara, 2018), some $2000 \mathrm{~km}$ as the crow flies, equivalent to the distance from Paris to Athens. Habu (2010) raises the possibility that the increase in dugout canoe numbers from the Late Jōmon was associated with craft specialisation and long-distance trade. Funadomari on Rebun Island seems to have served 
as a specialist Late Jōmon production site for flat shell beads. In the 1950s, it was suggested that these flat shell beads had diffused from the continent to Japan (cf. Kikuchi, 1986). The opposite route now seems more likely, but this proposal awaits detailed analyses of beads from continental sites (Fujisawa, 2013). Sakaguchi (2011, p. 301) raises the possibility that the Ishikari plain in southwest Hokkaido may have been a regional centre for long-distance trade in the Late Jommon. Sites such as Kashiwagi B have produced very carefully-made polished stone rods with knobs at both ends. While usually interpreted as ritual objects, the possibility that such rods could be balance-beams for weighing commodities also needs to be considered.

Vandkilde (2016) argues that the Bronze Age spanned a 'hyper-region' of connectivity which was not centred on core-periphery relationships. While further work is needed on possible world system relations in East Asia, the idea of ancient globalisation, or what Vandkilde calls 'bronzisation', may be a useful way to explore the changes in Jōmon society at this time. Vandkilde (2016, p. 106) notes that, 'bronze easily crossed boundaries between different techno-economic systems, social solutions, and cultural groupings', leading to a Bronze Age 'metacultural beyond' wherein the transcultural values of bronze became entangled with cultures over a wide area. Bronze 'invited translations of the transculturally exotic, hence making objects co-active in local strategies of power and distinction'; as a result, 'the Bronze Age is particularly rich in objects that were neither imports nor truly indigenous' (Vandkilde, 2016, p. 108). Even after the end of the Jōmon, there are a number of categories of material culture which were made to imitate bronze objects. These include shell bracelets and ceramic and stone mirrors. The concept of 'bronzisation' suggests the need for a re-evaluation of the strict typological approaches used in Japanese archaeology to examine both short- and long-distance influences on material culture.

One apparent difference between the process of 'bronzisation' proposed here for Late-Final Jōmon Japan and the situation on the Eurasian continent relates to violence and warfare. It has been widely argued that the Bronze Age marks the emergence of militarised societies, with professional specialists in warfare who used the new metal technology to deadly effect (Horn \& Kristiansen, 2018; Kristiansen, 1999). Molloy and Horn (2020, p. 117) write that 'the transformation of warfare in the Bronze Age was perhaps the most profound in human history and indeed for human history.' In Japan, there was a significant increase in violence and warfare in the Yayoi period (Hudson, 1990; Hudson et al., 2020), but it is widely assumed that levels of violence in the Jōmon period were low, and a recent review of previously published osteological reports has supported that conclusion (Nakao et al., 2016). However, few of the studies used by Nakao et al. (2016) were systematic analyses of violent trauma and it is clear that further such analyses will increase the skeletal evidence for violence in Jōmon society (Hudson et al., 2020). Such evidence will enable us to develop a better understanding of how the Bronze Age contacts discussed in this paper influenced patterns of violence and warfare in Japan.

Jennings (2011, pp. 123-141, 2016) suggests eight hallmarks of ancient globalisation: time/space compression, deterritorialisation, standardisation, unevenness, homogenisation, cultural heterogeneity, re-embedding of local culture, and 


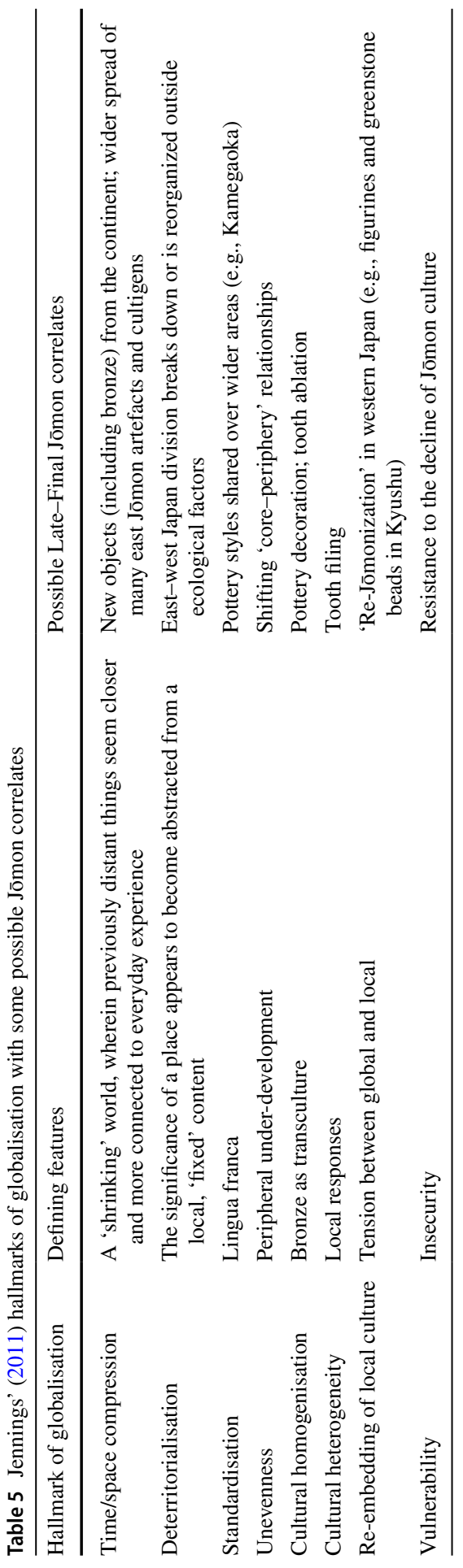


vulnerability. We suggest that each of these was to some extent present in Japan in the Late-Final Jōmon periods (Table 5).

\section{Conclusions}

Many of the objects analysed in this paper have a long history of research within Japanese archaeology, and various opinions have been expressed on their relationship with the cultures of the East Asian continent. Our aim here has not been to 'settle' this debate, and discussion of many of these artefacts will no doubt continue. Rather, the main objective of this paper has been to provide something that has been missing from the literature so far: a broad framework for thinking about relations between Japan and the rest of Eurasia during the Bronze Age. The Bronze Age was the time when a new demand for metal ores and other raw materials transformed Eurasian trade economies, moving them away from their previous focus on alluvial city states (Scott, 2017). In a process which Scott (2017) calls the 'Golden Age of the Barbarians' and Hudson (2020b) calls the 'secondary peoples' revolution', the resulting Bronze Age trade networks and population dispersals engendered new economic forms, such as nomadic pastoralism, as well as the spread of fullscale agriculture to previously peripheral regions. Based on an analysis of Middle to Final Jōmon Japan, we argue that these developments can be termed Bronze Age 'globalisation' or, following Vandkilde (2016), 'bronzisation'. Despite the highly peripheral location of the Japanese Islands in Eurasian prehistory, the Jōmon example discussed here shows just how powerful bronze was as a globalised transculture. Jōmon bronzisation may have led to shared values and perhaps began to break down previously resilient foraging modes of thought (cf. Barnard, 2007). The perspective of bronzisation provides a new way of looking at the Jomon which could potentially help to further integrate Japan into the broader story of Eurasian history.

Supplementary Information The online version contains supplementary material available at https://doi. org/10.1007/s10963-021-09156-6.

Acknowledgements The research leading to these results has received funding from the European Research Council (ERC) under the European Union's Horizon 2020 research and innovation programme (Grant Agreement No. 646612) granted to Martine Robbeets. We thank the two anonymous reviewers for their comments on the paper and Nick Márquez-Grant, Christopher Knüsel and Rick Schulting for their help with the taphonomic analysis of the Itoku site.

Funding Open Access funding enabled and organized by Projekt DEAL.

Open Access This article is licensed under a Creative Commons Attribution 4.0 International License, which permits use, sharing, adaptation, distribution and reproduction in any medium or format, as long as you give appropriate credit to the original author(s) and the source, provide a link to the Creative Commons licence, and indicate if changes were made. The images or other third party material in this article are included in the article's Creative Commons licence, unless indicated otherwise in a credit line to the material. If material is not included in the article's Creative Commons licence and your intended use is not permitted by statutory regulation or exceeds the permitted use, you will need to obtain permission directly from the copyright holder. To view a copy of this licence, visit http://creativecommons.org/licen ses/by/4.0/. 


\section{References}

Abe, C., Leipe, C., Tarasov, P. E., Müller, S., \& Wagner, M. (2016). Spatio-temporal distribution of archaeological sites in the Hokkaido region (northern Japan): An overview. The Holocene, 26, 1627-1645.

Ahn, S.-M. (2010). The emergence of rice agriculture in Korea: Archaeobotanical perspectives. Archaeological and Anthropological Sciences, 2, 89-98.

Ahn, S. M., Kim, J. S., \& Hwang, J. H. (2015). Sedentism, settlements, and radiocarbon dates of Neolithic Korea. Asian Perspectives, 54, 113-143.

Aikens, C. M. (2012). Origins of the Japanese people. In K. F. Friday (Ed.), Japan emerging: Premodern history to 1850 (pp. 55-65). Westview.

Akazawa, T. (1982). Cultural change in prehistoric Japan: Receptivity to rice agriculture in the Japanese archipelago. In F. Wendorf \& A. F. Close (Eds.), Advances in world archaeology (Vol. 1, pp. 151-212). Academic Press.

Akazawa, T. (1986). Hunter-gatherer adaptations and the transition to food production in Japan. In M. Zvelebil (Ed.), Hunters in transition: Mesolithic societies of temperate Eurasia and their transition to farming (pp. 151-165). Cambridge University Press.

Akazawa, T. (1988). Variability in the types of fishing adaptation of the later Jomon hunter-gatherers $\mathrm{c}$. 2500-300 bc. In G. N. Bailey \& J. Parkington (Eds.), The archaeology of prehistoric coastlines (pp. 78-92). Cambridge University Press.

Allentoft, M. E., et al. (2015). Population genomics of Bronze Age Eurasia. Nature, 522, 167-172.

An, Z. (1991). Continental roots of the earliest Japanese culture. In K. Hanihara (Ed.), Japanese as a member of the Asian and Pacific populations (pp. 173-186). Kyoto: International Research Center for Japanese Studies.

An, Z. (2002). Nihon shutsudo no rekijō doki ni tsuite (日本出土の鬲状土器について: Concerning the tripod-shaped pottery discovered in Japan). In T. Asakawa \& S. Abiko (Eds), Jōmon jidai no torai bunka: Kokumontsuki yūkō sekifu to sono shūhen (pp. 250-257). Yūzankaku. In Japanese.

Arcini, C. (2005). The Vikings bare their filed teeth. American Journal of Physical Anthropology, 128, $727-733$.

Arcini, C. (2007). Reconstructing daily life in past populations. In A. Kaliff (Ed.), Archaeology in the east and the west: Papers presented at the Sino-Sweden archaeology forum, Beijing in September 2005 (pp. 261-274). Stockholm: National Heritage Board.

Bae, C. J. (2017). Late Pleistocene human evolution in eastern Asia: Behavioral perspectives. Current Anthropology, 58(S17), S514-S526.

Bae, C. J., \& Kim, B. C. (2015). Korean prehistory: Current perspectives. Asian Perspectives, 54(1), $1-10$.

Bagley, R. W. (2004). Anyang writing and the origin of the Chinese writing system. In S. D. Houston (Ed.), The first writing: Script invention as history and process (pp. 190-249). Cambridge University Press.

Bale, M. (2001). The archaeology of early agriculture in the Korean peninsula: An update on recent developments. Bulletin of the Indo-Pacific Prehistory Association, 21, 77-84.

Barnard, A. (2007). From Mesolithic to Neolithic modes of thought. In A. Whittle \& V. Cummings (Eds.), Going over: The Mesolithic-Neolithic transition in north-west Europe (pp. 5-19). Oxford University Press.

Barnes, G. L. (1993). Miwa occupation in wider perspective. In G. L. Barnes \& M. Okiata (Eds.), The Miwa project: Survey, coring and excavation at the Miwa site, Nara, Japan (pp. 181-192). Oxford: Tempus Repartum (BAR International Series 582).

Barnes, G. L. (2014). Complex society in Korea and Japan. In C. Renfrew \& P. Bahn (Eds.), The Cambridge world prehistory (Vol. 2, East Asia and the Americas, pp. 833-851). Cambridge University Press.

Barnes, G. L. (2015). Archaeology of East Asia: The rise of civilization in China, Korea and Japan. Oxbow.

Bausch, I. R. (2004). Some considerations on Jomon serpentinite polished adze and jadeite ornament production sites along the Japan Sea coast. Bulletin of the International Jomon Culture Conference, 1, 15-24. 
Bausch, I. R. (2010a). Jade landscapes: Changing social values of jade in Jomon Japan. In Neomap Project (Ed.), Studies of landscape history on East Asian inland seas (pp. 57-68). Research Institute for Humanity and Nature.

Bausch, I. R. (2010b). Fragmentation practices in central Japan: Middle Jomon clay figurines at Shakado. In D. Gheorghiu \& A. Cyphers (Eds.), Zoomorphic miniature figures in Eurasia, Africa and MesoAmerica: Morphology, materiality, technology, function and context (pp. 99-112). Archaeopress.

Bausch, I. R. (2016). Prehistoric networks across the Korea strait (5000-1000 BCE): 'Early globalization' during the Jomon period in northwest Kyushu? In T. Hodos (Ed.), The Routledge handbook of archaeology and globalization (pp. 413-437). Routledge.

Bellwood, P. (2005). First farmers: The origins of agricultural societies. Blackwell.

Bleed, P., \& Matsui, A. (2010). Why didn't agriculture develop in Japan? A consideration of Jomon ecological style, niche construction, and the origins of domestication. Journal of Archaeological Method and Theory, 17, 356-370.

Boivin, N., Fuller, D. Q., \& Crowther, A. (2012). Old World globalization and the Columbian exchange: Comparison and contrast. World Archaeology, 44, 452-469.

Childe, V. G. (1950). The urban revolution. Town Planning Review, 21, 3-17.

Crawford, G. W. (2008). The Jomon in early agriculture discourse: Issues arising from Matsui, Kanehara and Pearson. World Archaeology, 40, 445-465.

Crawford, G. W. (2011). Advances in understanding early agriculture in Japan. Current Anthropology, 52(Supplement 4), S331-S345.

Crawford, G. W., \& Lee, G.-A. (2003). Agricultural origins in the Korean peninsula. Antiquity, 77, 87-95.

Crawford, G. W., \& Takamiya, H. (1990). The origins and implications of late prehistoric plant husbandry in northern Japan. Antiquity, 64, 889-911.

Dalfes, H. N., Kukla, G., \& Weiss, H. (Eds.). (1997). Third millennium BC climate change and Old World collapse. Springer.

D'Andrea, C. (1995). Later Jomon subsistence in northeastern Japan: New evidence from paleoethnobotanical studies. Asian Perspectives, 34, 195-227.

Dixon, C. (2004). Notes on the ceramic assemblage. In C. Mühlenbock \& C. Prescott (Eds.), The Scandinavian Sicilian Archaeological Project: Archaeological excavation at Monte Polizzo. Field Reports 1998-2001 (pp. 53-68). University of Göteborg Press.

Doi, T. (1992a). Broad blade-shaped objects. In R. J. Pearson (Ed.), Ancient Japan (p. 119). Arthur M. Sackler Gallery.

Doi, T. (1992b). Vessel with a spout. In R. J. Pearson (Ed.), Ancient Japan (p. 95). Arthur M. Sackler Gallery.

Esaka, T. (1965). Seiryūtō sekki kō (青龍刀系石器考: On the blue dragon sword type stone tools). Shigaku, 38(1), 75-102. In Japanese.

Fernandez-Jalvo, Y., \& Andrews, P. (2016). Atlas of taphonomic identifications: 1001+ images of fossil and recent mammal bone modification. Springer.

Fitzhugh, B., Gjesfjeld, E., Brown, W., Hudson, M., \& Shaw, J. (2016). Resilience and the population history of the Kuril Islands, northwest Pacific: A study in complex human ecodynamics. Quaternary International, 419, 165-193.

Fortescue, M. (2013). Polysynthesis in the Arctic/Sub-Arctic: How recent is it? In B. Bickel, L. A. Grenoble, D. A. Peterson, \& A. Timberlake (Eds.), Language typology and historical contingency: Festschrift for Johanna Nichols (pp. 241-264). John Benjamins.

Francis-Ratté, A. (2016). Proto-Korean-Japanese: A new reconstruction of the common origin of the Japanese and Korean languages. Ph.D. dissertation. Ohio: The Ohio State University.

Frank, A. G. (1993). Bronze Age world system cycles. Current Anthropology, 34, 383-429.

Fujio, S. (2015). Yayoi jidai no rekishi (弥生時代の歴史: The history of the Yayoi period). Kōdansha. In Japanese.

Fujisawa, T. (2013). Kaisei hiradama (貝製平玉: Flat shell beads). Kikan Kōkogaku, 125, 85-87. In Japanese.

Gansu Provincial Cultural Relics Work Team, Ningxia Hui Autonomous Region, and Dongxiang Autonomous County. (1984). Gansu Dongxiang Linjia yizhi fajue baogao (甘肃东乡林家遗址发掘报告: Report of excavations at the Linjia site in Dongxiang, Gansu Province). In: Kaoguxue Jikan (考古 学集刊: Archaeological Bulletin). Beijing: China Social Science Press. In Chinese.

Gibbs, K., \& Jordan, P. (2016). A comparative perspective on the 'western' and 'eastern' Neolithics of Eurasia: Ceramics, agriculture and sedentism. Quaternary International, 419, 27-35. 
Gilaizeau, L. (2010). Le rôle et l'influence du continent asiatique sur les sociétés de l'archipel japonais durant la protohistoire à travers les pratiques funéraires: Du Yayoi moyen au Kofun ancien ( $V^{e}$ siècle avant notre ère $-I V^{e}$ siècle de notre ère). Ph.D. dissertation, Université de Paris I - Panthéon Sorbonne.

Groot, G. J. (1951). The prehistory of Japan. Columbia University Press.

Habu, J. (2004). Ancient Jomon of Japan. Cambridge University Press.

Habu, J. (2010). Seafaring and the development of cultural complexity in northeast Asia: Evidence from the Japanese archipelago. In A. Anderson, J. H. Barrett, \& K. V. Boyle (Eds.), The global origins and development of seafaring (pp. 159-189). McDonald Institute for Archaeological Research.

Han, K., \& Nakahashi, T. (1996). A comparative study of ritual tooth ablation in ancient China and Japan. Anthropological Science, 104(1), 43-64.

Harada, M. (1992). Polished adzes. In R. J. Pearson (Ed.), Ancient Japan (p. 118). Arthur M. Sackler Gallery.

Harunari, H. (1986). Rules of residence in the Jōmon period, based on the analysis of tooth extraction. In R. J. Pearson, G. L. Barnes, \& K. L. Hutterer (Eds.), Windows on the Japanese past: Studies in archaeology and prehistory (pp. 293-310). Center for Japanese Studies, University of Michigan.

Hashiguchi, N. (1994). The Izu islands: Their role in the historical development of ancient Japan. Asian Perspectives, 33, 121-149.

Heggarty, P. (2007). Linguistics for archaeologists: Principles, methods and the case of the Incas. Cambridge Archaeological Journal, 17, 311-340.

Heine-Geldern, R. (1959). Lungshan culture and East Caspian culture, a link between prehistoric China and the ancient Near East: The origin and spread of writing. In Japanese National Commission for UNESCO (Ed.), International symposium on history of eastern and western cultural contacts (pp. 5-24). Tokyo: Japanese National Commission for UNESCO.

Hirao, Y., et al. (2001). Yamagata-ken Misakiyama shutsudo seidō tōshi no namari dōitai taihi (山形県三 崎山出土青銅刀子の鉛同位体対比:A comparison of lead isotopes from the bronze dagger from Misakiyama, Yamagata prefecture). Abstracts of the 18th Annual Meeting of the Japan Society for Scientific Studies on Cultural Properties (pp. 44-45).

Hongo, H. (2017). Introduction of domestic animals to the Japanese archipelago. In U. Albarella (Ed.), The Oxford handbook of zooarchaeology (pp. 333-350). Oxford University Press.

Horiuchi, A., Miyata, Y., Kamijo, N., Cramp, L., \& Evershed, R. (2015). A dietary study of the Kamegaoka culture population during the Final Jomon period, Japan, using stable isotope and lipid analyses of ceramic residues. Radiocarbon, 57, 721-736.

Horn, C., \& Kristiansen, K. (Eds.). (2018). Warfare in Bronze Age society. Cambridge University Press.

Hosoya, L. A. (2011). Staple or famine food? Ethnographic and archaeological approaches to nut processing in East Asian prehistory. Archaeological and Anthropological Sciences, 3, 7-17.

Hudson, M. J. (1990). From Toro to Yoshinogari: Changing perspectives on Yayoi period archeology. In G. Barnes (Ed.), Hoabinhian, Jomon, Yayoi, early Korean states: Bibliographic reviews of Far Eastern archaeology 1990 (pp. 63-111). Oxbow.

Hudson, M. J. (1999). Ruins of identity: Ethnogenesis in the Japanese Islands. University of Hawai' $\mathrm{i}$ Press.

Hudson, M. J. (2017). The historical ecology of colonialism and violence in Hokkaido, Sakhalin and the Kuril Islands, AD 1200-1900. In J. Habu, P. Lape, \& J. Olsen (Eds.), Handbook of East and Southeast Asian archaeology (pp. 695-706). Springer.

Hudson, M. J. (2020a). Slouching toward the Neolithic: Complexity, simplification and resilience in the Japanese archipelago. In G. R. Schug (Ed.), Routledge handbook of the bioarcheology of climate and environmental change (pp. 379-395). Routledge.

Hudson, M. J. (2020b). Language dispersals and the 'secondary peoples' revolution': A historical anthropology of the Transeurasian unity. In M. Robbeets \& A. Savelyev (Eds.), The Oxford guide to the Transeurasian languages (pp. 806-813). Oxford University Press.

Hudson, M. J., \& Barnes, G. L. (1991). Yoshinogari: A Yayoi settlement in northern Kyushu. Monumenta Nipponica, 46, 211-235.

Hudson, M. J. \& Robbeets, M. (2020). Archaeolinguistic evidence for the farming/language dispersal of Koreanic. Evolutionary Human Sciences, 2, e52. https://doi.org/10.1017/ehs.2020.49

Hudson, M. J., Schulting, R., \& Gilaizeau, L. (2020). The origins of violence and warfare in the Japanese Islands. In G. Fagan, L. Fibiger, M. Hudson, \& M. Trundle (Eds.), The Cambridge world history of violence (Volume 1, The prehistoric and ancient worlds, pp. 160-177). Cambridge University Press. 
Ichikawa, T. (2013). Sekitō, sekibō (石刀、石棒: Stone swords, stone rods). Kikan Kōkogaku, 125, 45-49. In Japanese.

Im, H.-J. (1995). The new archaeological data concerned with the cultural relationship between Korea and Japan in the Neolithic age. Korea Journal, 35(3), 31-39.

Ikawa-Smith, F. (1992). Kanjo-dori: Communal cemeteries of the Late Jomon in Hokkaido. In C. M. Aikens \& S. N. Rhee (Eds.), Pacific Northeast Asia in prehistory: Hunter-fisher-gatherers, farmers, and sociopolitical elites (pp. 83-89). Washington State University Press.

Ikeya, K. (2015). Maritime transport of obsidian in Japan during the Upper Paleolithic. In Y. Kaifu, M. Izuho, T. Goebel, H. Sato, \& A. Ono (Eds.), Emergence and diversity of modern human behavior in Paleolithic Asia (pp. 362-375). Texas A\&M Press.

Imamura, K. (1996). Prehistoric Japan: New perspectives on insular East Asia. UCL Press.

Imamura, M. (2007). Tanso 14 nendai kōsei sofuto RHC3.2 ni tsuite (炭素14年代較正ソフトRHC3.2 について: On the radiocarbon calibration program RHC3.2. Bulletin of the National Museum of Japanese History, 137, 79-88. In Japanese with English abstract.

Ishikawa, H. (2010). Nōkō shakai no seiritsu (農耕社会の成立: The origins of agricultural society). Iwanami.

Ishikawa, T. (2014). Social complexity in the Late Jomon period: The constitution of the Shimo'ota shell mound cemetery of the Boso peninsula, eastern Kanto, Japan. Japanese Journal of Archaeology, 2, 3-33.

Itakura, Y. (2013). Henpei kataba sekifu to dasei sekifu (扁平片刃石斧と打製石斧: Rectangular adzes and chipped axes). Kikan Kōkogaku, 125, 59-61. In Japanese.

Janhunen, J. (2016). Reconstructio externa linguae Ghiliacorum. Studia Orientalia, 117, 3-27.

Janik, L. (1998). The appearance of food procuring societies in the southeastern Baltic Sea region. In M. Zvelebil, R. Dennell, \& L. Domańska (Eds.), Harvesting the sea, farming the forest: The emergence of Neolithic societies in the Baltic region (pp. 237-243). Sheffield Academic Press.

Jennings, J. (2011). Globalizations and the ancient world. Cambridge University Press.

Jennings, J. (2016). Distinguishing past globalizations. In T. Hodos (Ed.), The Routledge handbook of archaeology and globalization (pp. 12-28). Routledge.

Kagawa, M. (1968). Problème de la civilisation agricole à l'époque de Ban en l'ère de Jômon: Technique du sabre en pierre (sekitô). Bulletin of Beppu University, 15, 1-17.

Kaner, S., \& Ishikawa, T. (2007). Reassessing the concept of the 'Neolithic' in the Jomon of western Japan. Documenta Praehistorica, 34, 1-7.

Kawasaki, T. (2002). Tairiku to Nihon rettō o musubu Nihonkai (大陸と日本列島を結ぶ日本海: The Sea of Japan links the continent with the Japanese archipelago). In T. Asakawa \& S. Abiko (Eds.), Jōmon jidai no torai bunka: kokumontsuke yūkō sekifu to sono shūhen (縄文時代の渡来 文化-刻文付有孔石斧とその周辺: The overseas cultural contacts of the Jomon period: On the incised perforated stone axe) (pp. 89-106). Yūzankaku. In Japanese.

Kawashima, T. (2008). Feasting and inter-village networks. Documenta Praehistorica, 35, $205-213$.

Kawashima, T. (2010). Mounds and rituals in the Jomon period. Documenta Praehistorica, 37, $185-192$.

Kawashima, T. (2013). Social change at the end of the Middle Jomon: A perspective from resilience theory. Documenta Praehistorica, 40, 227-232.

Kawashima, T. (2015a). Seisan to kyōen kara mita Jōmon jidai no shakaiteki fukuzatsuka (生産と饗 宴からみた縄文時代の社会的複雑化: Jommon social complexity as seen from production and feasting). Rokuichi Shobō. In Japanese.

Kawashima, T. (2015b). Prehistoric salt production Japan. In R. Brigand \& O. Weller (Eds.), Archaeology of salt: Approaching an invisible past (pp. 125-138). Sidestone.

Kawashima, T. (2016). Food processing and consumption in the Jōmon. Quaternary International, 404, $16-24$.

Kashiwakura, R. (1961). Misakiyama shutsudo no seidōtō (三崎山出土の青銅刀: The bronze knife from Misakiyama). Tōhoku Kōkogaku, 1, 1-12. In Japanese.

Kenrick, D. M. (1995). Jomon of Japan: The world's oldest pottery. Kegan Paul.

Kidder, J. E. (1957). The Jomon pottery of Japan. Ascona, Switzerland: Artibus Asiae Supplement 17.

Kidder, J. E. (1968). Painted barrel-shaped vessels of the Middle Jōmon period. Asian Perspectives, 11, 43-51.

Kidder, J. E. (1993). The earliest societies in Japan. Ancient JapanIn D. M. Brown (Ed.), Cambridge history of Japan (Vol. 1, pp. 48-107). Cambridge University Press. 
Kidder, J. E. (1995). Problems of Jōmon population decline. In Nogawa Site 1. Occasional Papers 9, ICU Archaeology Research Center (pp. 105-110). Tokyo: International Christian University.

Kidder, J. E. (2007). Himiko and Japan's elusive chiefdom of Yamatai: Archaeology, history, and mythology. University of Hawai' $i$ Press.

Kikuchi, T. (1986). Continental culture and Hokkaido. In R. J. Pearson, G. L. Barnes, \& K. L. Hutterer (Eds.), Windows on the Japanese past: Studies in archaeology and prehistory (pp. 149-162). Center for Japanese Studies, University of Michigan.

Kikuchi, T., Okauchi, M. \& Takahashi, R. (1996). Aomoriken Kokuzō iseki shutsudo doki no kyōdō kenkyū (青森県虚空蔵遺跡出土土器の共同研究: Collaborative research on the pottery excavated from the Kokuzō site, Aomori prefecture). Bulletin of the Graduate Division of Literature, Waseda University, 42, 81-103. In Japanese.

Kim, J. S. (2003). Land-use conflict and the rate of the transition to agricultural economy: A comparative study of southern Scandinavia and central-western Korea. Journal of Archaeological Method and Theory, 10, 277-321.

Kim, J. C., \& Bae, C. J. (2010). Radiocarbon dates documenting the Neolithic-Bronze Age transition in Korea. Radiocarbon, 52, 483-492.

Kim, J. C., Kim, D. K., Youn, M., Yun, C. C., Park, G., Woo, H. J., Hong, M. Y. \& Lee G. K. (2007). PIXE provenancing of obsidian artefacts from Palaeolithic sites in Korea. Bulletin of the IndoPacific Prehistory Association, 27, 122-128.

Kim, M., Shin, H-N., Kim, S., Lim, D-J., Jo, K., Ryu, A., Won, H., Oh, S. \& Noh, H. (2015). Population and social aggregation in the Neolithic Chulmun villages of Korea. Journal of Anthropological Archaeology, 40, 160-182.

Kinoshita, N. (2003). Shell trade and exchange in the prehistory of the Ryukyu archipelago. Bulletin of the Indo-Pacific Prehistory Association, 23, 67-72.

Kita, S. (1926). Oū chihō no Ainuzoku no tairiku kōtsū wa sude ni senshi jidai ni aru ka (奥羽地方のア イ又族の大陸交通は既に先史時代に有るか: Did the continental connections of the Ainu of the Oū region already exist in prehistory? Minzoku, l(2). In Japanese.

Kita, S. (1927). Oū hokubu no sekki jidai bunka ni okeru kodai Shina bunka no eikyō ni tsuite (奥羽北部 の石器時代文化における古代シナ文化の影響について: The influence of ancient China's culture on the Stone Age culture of the northern Oū region). Minzoku, 2(2).

Kobayashi, K. (2013). Uwahaba iseki shutsudo no ōgata masei sekifu (上掵遺跡出土の大型磨製石斧: The large polished stone axes from the Uwahaba site). Kikan Kökogaku, 125, 90-92. In Japanese.

Kobayashi, S. (2001). Eastern Japanese pottery during the Jomon-Yayoi transition: A study in foragerfarmer interaction. Bulletin of the Indo-Pacific Prehistory Association, 21, 37-42.

Kobayashi, T. (1992). Regional organization in the Jomon period. Arctic Anthropology, 29, 82-95.

Kōchi-ken Bunka Zaidan Maizōbunkazai Senta (Eds.). (2003). Itoku isekigun IV (居徳遺跡群IV: Itoku site group IV). Kōchi: Kōchi Prefecture. In Japanese.

Kodama, D. (2003). Komakino stone circle and its significance for the study of Jomon social structure. In J. Habu, J. M. Savelle, S. Koyama, \& H. Hongo (Eds.), Hunter-gatherers of the north Pacific rim. Senri Ethnological Studies 63 (pp. 235-261). National Museum of Ethnology.

Koike, H., \& Ohtaishi, N. (1985). Prehistoric hunting pressure estimated by the age composition of excavated sika deer (Cervus nippon) using the annual layer of tooth cement. Journal of Archaeological Science, 12, 443-456.

Komoto, M. (1982). Megalithic monuments in ancient Japan. In B.-M. Kim (Ed.), Megalithic cultures in Asia (pp. 4-40). Hanyang University Press.

Kondō, Y. (1962). Yayoi bunka (弥生文化: Yayoi culture). In S. Ienaga (Ed.), Iwanami kōza Nihon rekishi 1 (岩波講座日本歴史1: The Iwanami course on Japanese history) (Vol. 1, pp. 139-188). Tokyo: Iwanami. In Japanese.

Koyama, S. (1978). Jomon subsistence and population. Senri Ethnological Studies, 2, 1-65.

Koyama, S. (1981). A quantitative study of wild food resources: An example from Hida. Senri Ethnological Studies, 9, 91-115.

Kristiansen, K. (1999). The emergence of warrior aristocracies in later European prehistory. In J. Carman \& A. Harding (Eds.), Ancient warfare: Archaeological perspectives (pp. 175-189). Sutton Publishing.

Kristiansen, K. (2006). Eurasian transformations: Mobility, ecological change, and the transmission of social institutions in the third millennium and the early second millennium BCE. In A. Hornborg \& C. Crumley (Eds.), The world system and the earth system: Global socioenvironmental change and sustainability since the Neolithic (pp. 149-162). Left Coast Press. 
Kristiansen, K. (2015). The decline of the Neolithic and the rise of Bronze Age society. In C. Fowler, J. Harding, \& D. Hofman (Eds.), The Oxford handbook of Neolithic Europe (pp. 1093-1117). Oxford University Press.

Kristiansen, K., \& Larsson, T. B. (2005). The rise of Bronze Age society: Travels, transmissions and transformations. Cambridge University Press.

Kudo, Y., Kobayashi, M., Momohara, A., Noshiro, S., Nakamura, T., Okitsu, S., Yanagisawa, S., \& Okamoto, T. (2009). Chiba-ken Okinoshima iseki kara shutsudo shita Joōmon jidai soōki no asa kajitsu no ${ }^{14} \mathrm{C}$ nendai (千葉県沖ノ島遺跡から出土した縄文時代早期のアサ果実の ${ }^{14} \mathrm{C}$ 年代: Radiocarbon dating of fossil hemp fruits in the earliest Jomon period excavated from the Okinoshima site, Chiba, Japan. Japanese Journal of Historical Botany, 17, 27-31. In Japanese with English summary.

Kusaka, S., Ikarashi, T., Hyodo, F., Yumoto, T., \& Katayama, K. (2008). Variability in stable isotope ratios in two Late-Final Jomon communities in the Tokai coastal region and its relationship with sex and ritual tooth ablation. Anthropological Science, 116, 171-181.

Kusaka, S., Hyodo, F., Yumoto, T., \& Nakatsukasa, M. (2010). Carbon and nitrogen stable isotope analysis on the diet of Jomon populations from two coastal regions of Japan. Journal of Archaeological Science, 37, 1968-1977.

Kuzmin, Y. V. (2013a). The beginnings of prehistoric agriculture in the Russian Far East: Current evidence and concepts. Documenta Praehistorica, 40, 1-12.

Kuzmin, Y. V. (2013b). Two trajectories in the Neolithization of Eurasia: Pottery versus agriculture (spatiotemporal patterns). Radiocarbon, 55, 1304-1313.

Lee, G.-A. (2011). The transition from foraging to farming in prehistoric Korea. Current Anthropology, 52, 307-329.

Lee, G.-A. (2016). The spread of domesticated plant resources in prehistoric northeast Asia. In T. Hodos (Ed.), The Routledge handbook of archaeology and globalization (pp. 394-412). Routledge.

Lee, G.-A. (2017). The Chulmun period of Korea: Current findings and discourse on Korean Neolithic culture. In J. Habu, P. Lape, \& J. Olsen (Eds.), Handbook of East and Southeast Asian archaeology (pp. 451-481). Springer.

Li, T., Ning, C., Zhushchikhovskaya, I. S., Hudson, M. J., \& Robbeets, M. (2020). Millet agriculture dispersed from Northeast China to the Russian Far East: Integrating archaeology, genetics, and linguistics. Archaeological Research in Asia, 22, 100177.

Long, T., Wagner, M., Demske, D., Leipe, C., \& Tarasov, P. E. (2017). Cannabis in Eurasia: Origin of human use and Bronze Age trans-continental connections. Vegetation History and Archaeobotany, $26,245-258$.

Lyman, R. L. (1994). Vertebrate taphonomy. Cambridge University Press.

Matsugi, T. (2007). Nihon no rekishi ichi: rettō sōseiki (日本の歴史一ー列島創世記: History of Japan 1: The genesis of the archipelago). Shōgakukan. In Japanese.

Matsui, A. (2005). Jōmon jidai no kōsō (縄文時代の抗争: Conflict in the Jōmon period). Kikan Tōhokugaku, 3, 54-63. In Japanese.

Matsui, A., \& Kanehara, M. (2006). The question of prehistoric plant husbandry during the Jomon period in Japan. World Archaeology, 38, 259-273.

Matsumoto, N. (2005). Jōmon no mura to shakai (縄文のムラと社会: Jōmon villages and society). Iwanami. In Japanese.

Matsumoto, N. (2011). The cognitive foundation of long distance interaction and its relation to social contexts. In N. Matsumoto, H. Bessho, \& M. Tomii (Eds.), Coexistence and cultural transmission in East Asia (pp. 31-47). Left Coast Press.

Matsumoto, N. (2018a). Japan: The earliest evidence of complex technology for creating durable coloured goods. Open Archaeology, 4, 206-216.

Matsumoto, T. (2018b). Tsukurareta Emishi (つくられたエミシ: The created Emishi). Dōseisha. In Japanese.

Matsumoto, N., Habu, J., \& Matsui, A. (2017). Subsistence, sedentism, and social complexity among Jomon hunter-gatherers of the Japanese archipelago. In J. Habu, P. Lape, \& J. Olsen (Eds.), Handbook of East and Southeast Asian archaeology (pp. 437-450). Springer.

Matsumura, H., Anezaki, T., \& Ishida, H. (2001). A morphometric analysis of Jomon skeletons from the Funadomari site on Rebun island, Hokkaido, Japan. Anthropological Science, 109, 1-21.

Mihara, S., Miyamoto, K., Nakamura, T., \& Koike, H. (2004). 14C age determination for human bones during the Yayoi period: The calibration ambiguity around $2400 \mathrm{BP}$ and the marine reservoir effect. Nuclear Instruments and Methods in Physics Research B, 223-224, 700-704. 
Milne, J. (1881). The Stone Age in Japan; with notes on recent geological changes which have taken place. Journal of the Anthropological Institute of Great Britain and Ireland, 10, 389-423.

Miyamoto, K. (2008). Prehistoric interaction between the Korean peninsula and the Japanese archipelago through Tsushima and Iki islands. Bulletin of the Society for East Asian Archaeology, 2, 13-17.

Miyamoto, K. (2014). The initial spread of early agriculture into Northeast Asia. Asian Archaeology, 3, 1-12.

Miyamoto, K. (2018). Yayoi jidai kaishiki no jitsunendai sairon (弥生時代開始期の実年代再論: A new discussion of the actual date of the beginning of the Yayoi period. Kökogaku Zasshi, 100(2), 1-27. In Japanese with English summary.

Mizoguchi, K. (2017). Anthropomorphic clay figurines of the Jomon period of Japan. In T. Insoll (Ed.), The Oxford handbook of prehistoric figurines (pp. 521-544). Oxford University Press.

Molloy, B. \& Horn, C. (2020). Weapons, warriors and warfare in Bronze Age Europe In G. Fagan, L. Fibiger, M. Hudson \& M. Trundle (Eds.), The Cambridge world history of violence (Vol. 1: The prehistoric and ancient worlds, pp. 117-141). Cambridge: Cambridge University Press.

Morii, Y., Ishiguro, N., Watanobe, T., Nakano, M., Hongo, H., Matsui, A., \& Nishimoto, T. (2002). Ancient DNA reveals genetic lineage of Sus scrofa among archaeological sites in Japan. Anthropological Science, 110, 313-328.

Nakahashi, T. (1999). Transition from the Jomon to the Yayoi period in the northern Kyushu and Yamaguchi region as viewed from ritual tooth ablation and skeletal morphology. In K. Omoto (Ed.), Interdisciplinary perspectives on the origins of the Japanese (pp. 127-142). International Research Center for Japanese Studies.

Nakamura, O. (1999). Bosei kara yomu Jōmon shakai no kaisōka (墓制から読む縄文社会の階層化: The stratification of Jōmon society as seen from burials). In T. Kobayashi (Ed.), Jōmon no sekai ( 縄文学の世界: The world of Jomon studies) (pp. 48-60). Asahi Shinbunsha. In Japanese.

Nakao, H., Tamura, K., Arimatsu, Y., Nakagawa, T., Matsumoto, N., \& Matsugi, T. (2016). Violence in the prehistoric period of Japan: The spatio-temporal pattern of skeletal evidence for violence in the Jomon period. Biology Letters, 12, e20160028.

Nakayama, K. (1992). Jōmon bunka to tairikukei bunbutsu (縄文文化と大陸系文物 : Jōmon culture and continental artefacts). Kikan Kōkogaku, 38, 48-52. In Japanese.

Nakayama, S. (2010). Shokubutsu kōkogaku to Nihon no nōkō no kigen (植物考古学と日本の農耕の起 源: Archaeobotany and the origins of agriculture in Japan). Dōseisha. In Japanese.

Nakazawa, M. (2017). Nihon rettō ni okeru nōkō no denpa to teichaku (日本列島における農耕の伝 播と定着: The diffusion and establishment of agriculture in the Japanese archipelago). Kikan Kōkogaku, 138, 26-29. In Japanese.

Nakazawa, Y., \& Bae, C. J. (2018). Quaternary paleoenvironmental variation and its impact on human dispersals into the Japanese Archipelago. Palaeogeography, Palaeoclimatology, Palaeoecology, $512,145-155$.

Nasu, H., \& Momohara, A. (2016). The beginnings of rice and millet agriculture in prehistoric Japan. Quaternary International, 397, 504-512.

Naumann, N. (2000). Japanese prehistory: The material and spiritual culture of the Jomon period. Harrassowitz Verlag.

Nelson, S. M. (1993). The archaeology of Korea. Cambridge University Press.

Nelson, S. (1999). Megalithic monuments and the introduction of rice into Korea. In C. Gosden \& J. Hather (Eds.), The prehistory of food: Appetites for change (pp. 147-165). Routledge.

Nichols, J. (2011). Forerunners to globalization: The Eurasian steppe and its periphery. In C. Hasselblatt, P. Houtzagers, \& R. van Pareren (Eds.), Language contact in times of globalization (pp. 177-195). Rodopi.

Niigata Prefecture Archaeology Operations Centre (Ed.). (2019). Dobashikita iseki (土橋北遺跡: Dobashikita site). Niigata: Niigata Prefecture Board of Education.

Nishimura, Y. (2018). The evolution of curved beads (magatama) in Jōmon period Japan and the development of individual ownership. Asian Perspectives, 57, 105-158.

Nishiwaki, T. (1998). Sekken nōto (石剣ノート: A note on stone swords). In Y. Hirakawa (Ed.), Hoppō no kōkogaku (北方の考古学: The archaeology of the north) (pp. 209-224). Nomura Takashi Kanreki Kinen Ronshū Kankōkai. In Japanese.

Nishiwaki, T. (2008). Sekken to seidō tanken (石棒と青銅短剣: Stone rods and bronze daggers). In Shiretoko Museum (Ed.), Shiretoko no kōkogaku (知床の考古: The archaeology of Shiretoko) (pp. 121-124). Shari: Shari Town and Board of Education. In Japanese. 
Northeast Asian History Foundation. (2007). Xiajiadian Shangceng Wenhua de Qingtongqi (夏家店上 辰文化的青銅器: The Upper Xiajiadian bronze artifacts. Northeast Asian History Foundation. In Chinese and Korean.

Nomura, T. (1985). Hokkaidō Jōmon jidai shūmatsuki no kenkyū (北海道縄文時代終末期の研究: Research on the final stage of the Jōmon in Hokkaido). Miyama Shobō. In Japanese.

Norton, C. J. (2007). Sedentism, territorial circumsciption, and the increased use of plant domesticates across Neolithic-Bronze Age Korea. Asian Perspectives, 46, 133-165.

Nunome, J. (1985). Asa to kinu (麻と絹: Hemp and silk). In H. Kanaseki \& M. Sahara (Eds.), Yayoi bunka no kenkyū 5: dōgu to gijutsu (弥生文化の研究5一道具と技術: Research on Yayoi culture, Vol. 5: Tools and technologies I) (pp. 184-188). Yūzankaku. In Japanese.

Obata, H. (2016). Tane o maku Jōmonjin: Saishin kagaku ga kutsugaesu nōkō no kigen (タネをまく縄 文人一最新科学が覆す農耕の起源: The seed-sowing Jōmon people: Recent science overturns the origins of agriculture). Yoshikawa Kōbunkan. In Japanese.

Oh, Y., Conte, M., Kang, S., Kim, J., \& Hwang, J. (2017). Population fluctuation and the adoption of food production in prehistoric Korea: Using radiocarbon dates as a proxy for population change. Radiocarbon, 59(6), 1761-1770.

Oikawa, A., \& Koyama, S. (1981). A Jomon shellmound database. Senri Ethnological Studies, 9, 187-199.

Perri, A. R. (2016). Hunting dogs as environmental adaptations in Jōmon Japan. Antiquity, 90, 1166-1180.

Rascovan, N., Sjögren, K.-G., Kristiansen, K., Nielsen, R., Willerslev, E., Desnues, C., \& Rasmussen, S. (2019). Emergence and spread of basal lineages of Yersinia pestis during the Neolithic decline. Cell, 176, 295-305.

Ratnagar, S. (2001). The bronze age: Unique instance of a pre-industrial world system? Current Anthropology, 42(3), 351-379. https://doi.org/10.2307/3596622

Robbeets, M. (2005). Is Japanese related to Korean, Tungusic, Mongolic and Turkic? Harrassowitz.

Robbeets, M. (2017). The language of the Transeurasian farmers. In M. Robbeets \& A. Savelyev (Eds.), Language dispersal beyond farming (pp. 93-121). John Benjamins.

Roksandic, Z., Minagawa, M., \& Akazawa, T. (1988). Comparative analysis of dietary habits between Jomon and Ainu hunter-gatherers from stable carbon isotopes of human bone. Journal of the Anthropological Society of Nippon, 96, 391-404.

Sakaguchi, T. (2007). Refuse patterning and behavioral analysis in a pinniped hunting camp in the Late Jomon period: A case study in layer $\mathrm{V}$ at the Hamanaka 2 site, Rebun island, Hokkaido, Japan. Journal of Anthropological Archaeology, 26, 28-46.

Sakaguchi, T. (2011). Mortuary variability and status differentiation in the Late Jomon of Hokkaido based on the analysis of shuteibo (communal cemeteries). Journal of World Prehistory, 24, 275-308.

Sasaki, Y., Kudō, Y. \& Momohara, A. (2007). Tōkyōto Shimoyakebe iseki no ōgata shokubutsu itai kara mita Jōmon jidai kōhanki no shokubutsu shigen riyō (東京都下宅部遺跡の大型植物遺体から みた縄文時代後半期の植物資源利用: Utilisation of plant resources reconstructed from plant microfossils during the latter half of the Jomon period at the Shimo-yakebe site, Tokyo). Japanese Journal of Historical Botany, 15, 35-50. In Japanese.

Sasaki, Y., \& Noshiro, S. (2018). Did a cooling event in the middle to late Jomon periods induced [sic] change in the use of plant resources in Japan? Quaternary International, 471, 369-384.

Satō, Y. (2000). Yamagata-ken Shōnai shutsudo no yūkō sekifu to seidōtō (山形県庄内出土の有孔石斧 と青銅刀: The perforated stone axe and bronze knife excavated from the Shōnai district, Yamagata prefecture). Kōkogaku Jānaru, 454, 16-20. In Japanese.

Scott, J. C. (2017). Against the grain: A deep history of the earliest states. Yale University Press.

Shelach, G. (2005). Early pastoral societies of northeast China: Local change and interregional interaction during c. 1100-600 BCE. In R. Amitai \& M. Biran (Eds.), Mongols, Turks, and others: Eurasian nomads and the sedentary world (pp. 15-58). Brill.

Shintani, T., \& Okada, Y. (1986). Aomori-ken Tairadate son Imazu iseki shutsudo no jōsansoku doki (青森県平楯村今津遺跡出土の状三足土器: The three-legged pot excavated from the Imazu site, Tairadate village, Aomori prefecture). Kōkogaku Zasshi, 71, 241-246. In Japanese.

Shitara, H. (2018). Nansei shotō no Ōborakei doki to sono shūhen (南西諸島の大洞系土器とその周辺: On the Ōbora type pottery of the Ryukyu Islands). Tōkyō Daigaku Kōkogaku Kenkyūshitsu Kenkȳu Kiyō, 31, 47-60. In Japanese with English summary.

Shoda, S. (2010). Radiocarbon and archaeology in Japan and Korea: What has changed because of the Yayoi dating controversy? Radiocarbon, 52, 421-427. 
Shoda, S., Yanshina, O., Son, J.-H., \& Teramae, N. (2009). New interpretation of the stone replicas in the Russian Maritime Province: Re-evaluation from the perspective of Korean archaeology. The Review of Korean Studies, 12, 187-210.

Shōnai, A. (1999). Higashinaruseson Uwahaba iseki ni okeru ōgata masei sekifu no hakken jōkyō (東成 瀬村上掵遺跡における大型磨製石斧の発見状況: The discovery circumstances of the polished stone axes from the Uwahaba site, Higashinaruse village). Akita Kenritsu Hakubutsukan Kenkyū Hōkoku, 24, 61-68. In Japanese.

von Siebold, H. (1879). Notes on Japanese archaology, with especial reference to the Stone Age. C. Lévy. Sofaer, J. (2010). Technology and craft. In T. Earle \& K. Kristiansen (Eds.), Organizing Bronze Age societies: The Mediterranean, central Europe, and Scandinavia compared (pp. 185-217). Cambridge University Press.

Sofaer, J., Jørgensen, L. B., \& Choyke, A. (2013). Craft production: Ceramics, textiles, and bone. In H. Fokkens \& A. Harding (Eds.), The Oxford handbook of the European Bronze Age (pp. 469-491). Oxford University Press.

Tabarev, A. V. (2014). The later prehistory of the Russian Far East. East Asia and the AmericasIn C. Renfrew \& P. Bahn (Eds.), The Cambridge world prehistory (Vol. 2, pp. 852-869). Cambridge University Press.

Takahashi, R. (2004). Jōmon bunka kenkyū no saizensen (縄文文化研究の最前線: The front line of research on Jommon culture). Faculty of Letters, Waseda University. In Japanese.

Takahashi, R., Toizumi, T., \& Kojo, Y. (1998). Archaeological studies of Japan: Current studies of the Jomon archaeology. Nihon Kōkogaku, 5, 47-72.

Takamiya, H., Hudson, M. J., Yonenobu, H., Kurozumi, T., \& Toizumi, T. (2016). An extraordinary case in human history: Prehistoric hunter-gatherer adaptation to the islands of the central Ryukyus (Okinawa and Amami archipelagos), Japan. Holocene, 26, 408-422.

Takase, K. (2020). Long-term marine resource use in Hokkaido, northern Japan: New insights into sea mammal hunting and fishing. World Archaeology, 51, 408-428.

Takenaka, M., Mine, K., Tsuchimochi, K., \& Shimada, K. (2001). Tooth removal during ritual tooth ablation in the Jomon period. Bulletin of the Indo-Pacific Prehistory Association, 21, 49-52.

Temple, D. H., Kusaka, S., \& Sciulli, P. W. (2011). Patterns of social identity in relation to tooth ablation among prehistoric Jomon foragers from the Yoshigo site, Aichi prefecture, Japan. International Journal of Osteoarchaeology, 21, 323-335.

Teramae, N. (2017). Bunmei ni kōshita Yayoi no hitobito (文明に抗した弥生の人びと: The Yayoi people who resisted civilisation). Yoshikawa Kōbunkan. In Japanese.

Thomason, S. G., \& Kaufman, T. (1988). Language contact, creolization, and genetic linguistics. University of California Press.

Tsutsui, W. M. (2003). Landscapes in the dark valley: Toward an environmental history of wartime Japan. Environmental History, 8, 294-311.

Twiss, K. C. (2001). Problems of cultural change in the Late and Final Jomon. Bulletin of the Indo-Pacific Prehistory Association, 21, 30-36.

Uchiyama, J. (2006). The environmental troublemaker's burden? Jomon perspectives on foraging land use change. In C. Grier, J. Kim, \& J. Uchiyama (Eds.), Beyond affluent foragers: Rethinking huntergatherer complexity (pp. 136-167). Oxbow.

Uchiyama, J. (2008). Vertical or horizontal landscape? The prehistoric long-term perspectives on the history of the East Asian Inland Seas. In A. Schottenhammer (Ed.), The East Asian 'Mediterranean': Maritime crossroads of culture, commerce and human migration (pp. 25-52). Harrassowitz.

Uchiyama, J. (2017). Neolithization: A perspective from the East Asian Inland Seas. In Y. Yasuda \& M. J. Hudson (Eds.), Multidisciplinary studies of the environment and civilization: Japanese perspectives (pp. 133-158). Routledge.

Unger, J. M. (2009). The role of contact in the origins of the Japanese and Korean languages. University of Hawai 'i Press.

Vandkilde, H. (2016). Bronzization: The Bronze Age as pre-modern globalization. Praehistorische Zeitschrift, 91, 103-123.

Villa, P., \& Mahieu, E. (1991). Breakage patterns of human long bones. Journal of Human Evolution, 21, $27-48$.

Vovin, A. (1993). A reconstruction of proto-Ainu. Brill.

Wagner, M. \& Tarasov, P. (2014). The Neolithic of northern and central China. In C. Renfrew \& P. Bahn (Eds.), The Cambridge world prehistory. (Vol. 2, East Asia and the Americas, pp. 742-764). Cambridge: Cambridge University Press. 
Wang, M., \& Piao, W. (2016). Zhongguo Dongbei yu Dongbeiya Gudai Jiaotongshi (中国东北与东北亚 古代交通史: The history of transportation in ancient northeast China and northeast Asia). Liaoning People's Publishing House. In Chinese.

Whitman, J. (1985). The phonological basis for the comparison of Japanese and Korean. Ph.D. dissertation. Cambridge: Harvard University.

Whitman, J. (2012). The relationship between Japanese and Korean. In N. Tranter (Ed.), The languages of Japan and Korea (pp. 24-38). Routledge.

Wu, W. (2011). Liangzhou zhongyuan yu chu qiqi yishu zhong de keji bijiao (两周中原与楚漆器艺术 中的科技比较: Science and technology comparison of lacquer ware arts of the Central Plains and the state of Chu in the Zhou dynasty). Kexue Jishu Zhexue Yanjiu (studies in Philosophy of Science and Technology), 28, 78-83. In Chinese.

Yamanouchi, S. (1932). Nihon enko no bunka 2: Jōmon doki no kigen (日本遠古之文化 2: 縄紋土器之 起源: Japan's ancient culture 2: The origins of Jomon pottery). Dorumen, 1(5). In Japanese.

Yamanouchi, S. (1972). Setonai hōmen? no igata masei sekifu( 瀬戸内方面?の異形磨製石斧: An unusual polished stone axe from the Inland Sea (?) region). Senshi Kōkogaku Ronbunshū, 5, 239-240. (in Japanese).

Yamaura, K. (1998). The sea mammal hunting cultures of the Okhotsk Sea with special reference to Hokkaido prehistory. Arctic Anthropology, 35, 321-334.

Yanshina, O., \& Shoda, S. (2014). Weapon-shaped stone tools from the Russian Far East: The museum collections. Nara National Research Institute for Cultural Properties.

Zhang, Z. (1999). Hollow-footed tripodal pottery vessels from the Yellow River basin. Journal of East Asian Archaeology, 1(1-4), 149-193.

Zvelebil, M. (1998). Agricultural frontiers, Neolithic origins, and the transition to farming in the Baltic basin. In M. Zvelebil, R. Dennell, \& L. Domańska (Eds.), Harvesting the sea, farming the forest: The emergence of Neolithic societies in the Baltic region (pp. 9-27). Sheffield Academic Press.

Zvelebil, M. (2008). Innovating hunter-gatherers: The Mesolithic in the Baltic. In G. Bailey \& P. Spikins (Eds.), Mesolithic Europe (pp. 18-59). Cambridge University Press.

Zvelebil, M., \& Rowley-Conwy, P. (1984). Transition to farming in northern Europe: A hunter-gatherer perspective. Norwegian Archaeological Review, 17, 104-128.

Publisher's Note Springer Nature remains neutral with regard to jurisdictional claims in published maps and institutional affiliations.

\section{Authors and Affiliations}

\section{Mark J. Hudson ${ }^{1,2} \cdot$ Ilona R. Bausch ${ }^{3,4,5} \cdot$ Martine Robbeets $^{1} \cdot$ Tao Li $^{6}$. J. Alyssa White ${ }^{7} \cdot$ Linda Gilaizeau $^{1}$}

1 Archaeolinguistic Research Group, Department of Archaeology, Max Planck Institute for the Science of Human History, 07745 Jena, Germany

2 Institut d'Asie Orientale, École Normale Supérieure de Lyon, 15 parvis René Descartes, 69342 Lyon, France

3 Leiden University Institute of Area Studies, Matthias de Vrieshof 3, 2311 BZ Leiden, Netherlands

4 Sainsbury Institute for the Study of Japanese Arts and Cultures, 64 The Close, Norwich NR1 4DH, UK

5 Kokugakuin University Museum, 4-10-28 Higashi, Shibuya-ku, Tokyo 150-8440, Japan

6 Department of Archaeology, School of History, Wuhan University, Wuhan 430072, China

7 School of Archaeology, University of Oxford, 36 Beaumont St., Oxford OX1 2PG, UK 